\title{
Composition of clastic sediments in the Somosaguas area (middle Miocene, Madrid Basin): insights into provenance and palaeoclimate
}

\author{
O. Fesharaki ${ }^{1 *}$, J. Arribas ${ }^{2,3}$, N. López Martínez ${ }^{1,+}$ \\ ${ }^{1}$ Departamento de Paleontología, Facultad CC. Geológicas, Universidad Complutese de Madrid, 28040 Madrid, Spain. \\ ${ }^{2}$ Departamento de Petrología y Geoquímica, Facultad CC. Geológicas, Universidad Complutese de Madrid, \\ 28040 Madrid, Spain. \\ ${ }^{3}$ Instituto de Geociencias IGEO (CSIC, UCM) c. José Antonio Nováis, 12, 28040 Madrid, Spain \\ Deceased December 2010 \\ e-mail addresses: omidfesharaki@hotmail.com (O.F., *corresponding author); arribas@geo.ucm.es (J.A.)
}

Received: 4 April 2014 / Accepted: 10 March 2015 / Available online: 20 July 2015

\begin{abstract}
The western area of the Cenozoic Madrid Basin has not been adequately studied. This, combined with the high homogeneity of detrital facies makes the stratigraphic correlation with other areas of the basin rather difficult. Consequently, only a detailed characterization of different study zones can allow subsequent correlation over this area. Over the last years there have been discovered several vertebrate fossil sites in this area that allow the dating of the sediments which host the fossil remains and provide data about palaeoclimatic trends. In this paper we present the results of the light minerals petrographic analysis carried out in one of these sites (Somosaguas paleontological site). Previous palaeontological and isotopic studies in this site indicate a climate event of cooling and rising aridity that has been described globally for the period after the Miocene Climatic Optimum. The petrographic data and indices presented here corroborate this trend towards a more arid climate through the Somosaguas sedimentary succession. Besides we study the grades of alteration of plagioclase grains as a proxy in the evaluation of palaeoclimatic variations. The increase towards the top of the succession of less altered plagioclase grains suggests a decrease in precipitations and thus more aridity. Part of the quartz and K-feldspar grains display several features like embayments and alterations pointing to palaeosoils formation and reworking processes. These characteristics and other observations suggest several sedimentary pulses in a geotectonic setting of "basement uplift" and a mixed lithological provenance for the Somosaguas deposits (granites, gneisses and minor quantities of low-grade metamorphic rocks).
\end{abstract}

Keywords: middle Aragonian, Miocene Climatic Optimum, aridity, palaeosol, plagioclase alteration, sand

\section{Resumen}

La zona occidental de la cuenca de Madrid no ha sido adecuadamente estudiada. Esto, combinado con la alta homogeneidad de facies detríticas dificulta la correlación estratigráfica con otras áreas de la cuenca. En consecuencia, sólo una caracterización detallada de diferentes zonas de estudio puede permitir posteriores trabajos de correlación regional. En los últimos años se han descubierto varios yacimientos de fósiles de vertebrados en esta área que permiten la datación de los sedimentos que albergan estos restos y proporcionan datos paleoclimáticos. En este trabajo se presentan los resultados de los análisis composicionales de minerales ligeros realizados en uno de estos yacimientos (yacimiento paleontológico de Somosaguas). Estudios paleontológicos e isotópicos previos en este yacimiento registran un evento climático de enfriamiento y aumento de la aridez que se ha descrito a nivel mundial para el período posterior al Óptimo Climático del Mioceno. Los datos e índices petrográficos presentados en este trabajo corroboran la tendencia hacia un clima más árido a lo largo de la sucesión sedimentaria de Somosaguas. Además, se estudian los grados de alteración de los granos de plagioclasa como proxy en la evaluación de variaciones paleoclimáticas. El aumento hacia la parte superior de la sucesión de plagioclasas poco alteradas sugiere una disminución de las precipitaciones y por tanto mayor aridez. Parte de los granos de cuarzo y de feldespato muestran golfos de corrosión o alteraciones que indican procesos de formación de paleosuelos y de retrabajamiento. Estas características junto a otras observaciones sugieren varios pulsos sedimentarios en un entorno geotectónico de "basamento elevado" y una procedencia litológica mixta (granito, gneis y rocas metamórficas de bajo grado).

Palabras clave: Aragoniense medio, Óptimo Climático del Mioceno, aridez, paleosuelos, alteración de plagioclasas, arenas 


\section{Introduction}

The Cenozoic Madrid Basin forms part of the larger Tajo Basin, an intracratonic basin of the Iberian Peninsula. The pensinsula's Cenozoic basins are the outcome of convergence between the African and European plates, the formation of the Atlantic Ocean and the structuring of the Western Mediterranean Basin (Vegas and Banda, 1982; De Vicente et al., 1996). All these events are consistent with the Alpine Orogeny dynamics that rejuvenated or formed the mountain edges limiting the Tajo Basin (De Vicente et al., 2007). The Madrid Basin is bounded by three main mountain ranges: the Spanish Central System to the north (Somosierra mountains, composed of slates, phyllites and quartzites) and west (Guadarrama Sierra, mainly composed of granodiorites, biotitic granites, gneisses, pegmatites and schists), the Iberian Range to the east (mainly composed of limestones, dolostones, marls and arenites) and the igneous metamorphic series of the Toledo Mountains to the south (Aparicio-Yagüe and García-Cacho, 1984; Calvo, 1989a; Villaseca et al., 1993; Sopeña et al., 2004). During the Upper Palaeogene, the Tajo Basin was subdivided into the Madrid and Loranca Basins by north-south uplift of the Altomira Range. The Madrid Basin was filled with Tertiary sediments, both Palaeogene (Arribas, 1985; Arribas and Arribas, 1991) and Neogene (mainly Miocene) in age (Alonso-Zarza et al., 2004).

During the Miocene, substantial sedimentary infill of the Madrid Basin occurred as the result of erosion of the mountain edges of this basin caused by intense tectonic activity in the Spanish Central System (De Vicente et al., 1996). The different lithologies and origins of such mountainous borders gave rise to a variety of facies and to complex lateral changes between facies and towards the basin centre (Alonso-Zarza et al., 2004). In contrast, sediments at the western margin of the basin are relatively homogenous in their composition and facies (López-Olmedo et al., 2004). This makes difficult the facies correlation within this area and with other areas of the basin, where Neogene Major Tectosedimentary Units have been defined (Junco and Calvo, 1983; Ordóñez et al., 1991; Alonso-Zarza and Calvo, 2002). For this reason, only a very detailed characterization of the mineralogy, petrology and sedimementology of different zones on the western part of the Madrid Basin can allow future reliable stratigraphic correlations.

The Madrid Basin contains many Neogene deposits with fossil vertebrate remains facilitating the dating of sedimentary formations and their correlation (Peláez-Campomanes et al., 2003; Hernández-Ballarín et al., 2011, and references therein). Further, these palaeontological sites offer considerable palaeoenvironmental and palaeoclimate information on this particular time period, especially for the Miocene (Van der Meulen and Daams, 1992; Calvo et al., 1993; Hernández Fernández et al., 2006).
The Middle Miocene experienced remarkable climate changes with evidence suggesting a sharp drop in temperatures and an increase in aridity after the Miocene Climatic Optimum, a warm and humid period between 17 and $14 \mathrm{Ma}$ (Zachos et al., 2001; Böhme, 2003). These climate perturbations coincide in time with the formation of the Somosaguas palaeontological site (Domingo et al., 2009, 2012a; García Yelo et al., 2014; see Fesharaki et al., 2012 for a complete bibliographic references list about this palaeontological site). Previous palaeoclimatic and palaeoenvironmental inferences based on the abundance and variety of fauna and its characteristics, together with sedimentological, mineralogical and isotope data obtained for the Somosaguas site, have assigned this site to a period of worldwide climate changes (López Martínez et al., 2000; Mínguez Gandú, 2000; Hernández Fernández et al., 2006; Fesharaki et al., 2007; Carrasco et al., 2008; Domingo et al., 2009; Perales et al., 2009; García Yelo et al., 2014). This available data make it an ideal location to extend palaeoclimate studies to other scientific fields such as light mineral petrology. To make petrological data more reliable for paleoclimatic studies is important to consider the possible diagenetic changes undergone by the sediments analyzed. Previous studies have indicated little or no influence of diagenesis on the sediments of Somosaguas site (Fesharaki, 2005; Domingo et al., 2009, 2012b).

Sand and sandstone petrography is a useful tool to deduce both the geotectonic setting (Ingersoll, 1978; Dickinson and Suczek, 1979; Dickinson and Valloni, 1980; Dickinson et al., 1983; Dickinson, 1985) and lithology of a source area (Blatt, 1967; Dickinson, 1970; Pettijohn et al., 1972; Basu, 1976; Mack, 1981; Palomares and Arribas, 1993; Arribas and Tortosa, 2003). Factors such as relief, transport and climate are likely to modify the final composition of a sand deposit (Johnsson, 1993) and, together with source lithology and tectonics, define the concept of provenance (Basu, 1985). Several studies have addressed the relationship between climate and sandy deposit composition in present-day sediments (Young et al., 1975; Basu, 1976; Suttner et al., 1981; Franzinelli and Potter, 1983) which serves as a base for palaeoclimatic interpretations of older sediments. To better understanding the roles of these factors in determining sand composition, actualistic research has addressed fluvial to transitional and marine deposits worldwide (Ingersoll and Suczek, 1979; Le Pera and Critelli, 1997; Le Pera et al., 2001) including river sediments of the Madrid Basin (Arribas et al., 2000; Arribas and Tortosa, 2003; Le Pera and Arribas, 2004).

This paper addresses sand petrofacies formed during the Middle Aragonian (14.2Ma) at the Somosaguas palaeontological site (Madrid Basin), the evolution of their source area (Spanish Central System) and the climate that prevailed over the middle Miocene in this area. To this end, we also used data reported for recent materials arising from the same source area as the sands of the Somosaguas site (Palomares et 
Fig. 1.- Location maps of the studied sediments. A) Geological map showing the distribution of facies in the Intermediate Unit of the Madrid Basin Miocene sediments and the location of the Somosaguas palaeontological site (modified from Calvo et al., 1989); B) Detailed localization of the stratigraphic sections (S, 3, 4 and $\mathrm{N}$ ) sampled in this study..

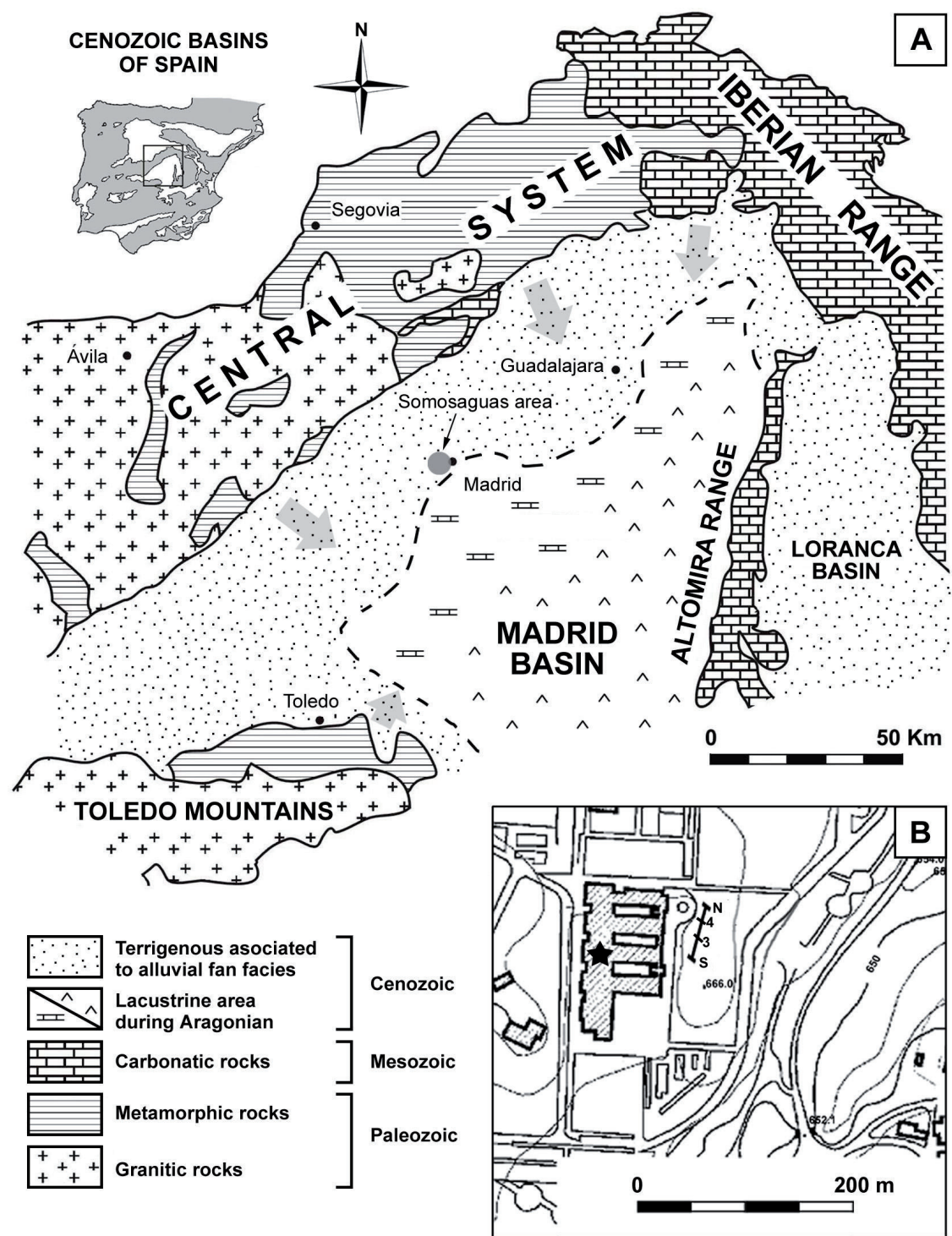

al., 1990; Palomares and Arribas, 1993; Tortosa et al., 1988, $1989,1991)$ as well as data emerging from sedimentological and clay mineralogy studies performed at the site itself (Mínguez Gandú, 2000; Fesharaki, 2005; Fesharaki et al., 2007). Finally, this paper contributes to the existing database on the provenance of sands filling intracratonic basins.

\section{Geological setting}

The Somosaguas palaeontological site lies within the Somosaguas campus of the Complutense University of Madrid (López Martínez et al., 2000) in the district of Pozuelo de Alarcón, on the west side of Madrid (Fig. 1). This site consists of two superposed fossiliferous levels of middle Miocene age (Biozone E, MN5, middle Aragonian, 14.2Ma; Luís and Hernando, 2000) contained in arkosic sands deposited by alluvial fan systems of the Spanish Central System mountains found in the northwest of the Tajo Basin (Mínguez Gandú, 2000). From the middle Miocene and coinciding with the deposition of the Somosaguas sediments, alluvial systems associated with these mountains penetrated more towards the basin, as a result of renewed tectonic activity at this basin's edge (Calvo et al., 1989a,b; De Vicente et al., 1996).

The Somosaguas site belongs to the Intermediate Tectosedimentary Unit (Megías et al., 1983; Mínguez Gandú, 2000) and occupies a shaly corridor, the Majadahonda shaly corridor, which separates two sandy NW-SE trending bands that make up the Colmenar and Marchamalo alluvial fans (Torres et al., 1995; Carrasco et al., 2008). These sandy fans form part of the alluvial fan systems that supply detrital sediments to the Madrid Basin. The Central System, presumably the source area for the Somosaguas sediments (Fesharaki, 2005), in its western and northwestern zones shows a granite/gneiss composition while its eastern area contains low-grade metamorphic rocks (Calvo, 1989a).

\section{Stratigraphic framework}

Four NE-SW trending stratigraphic sections of the Somosaguas site were examined (Fig. 1b). The maximum eleva- 


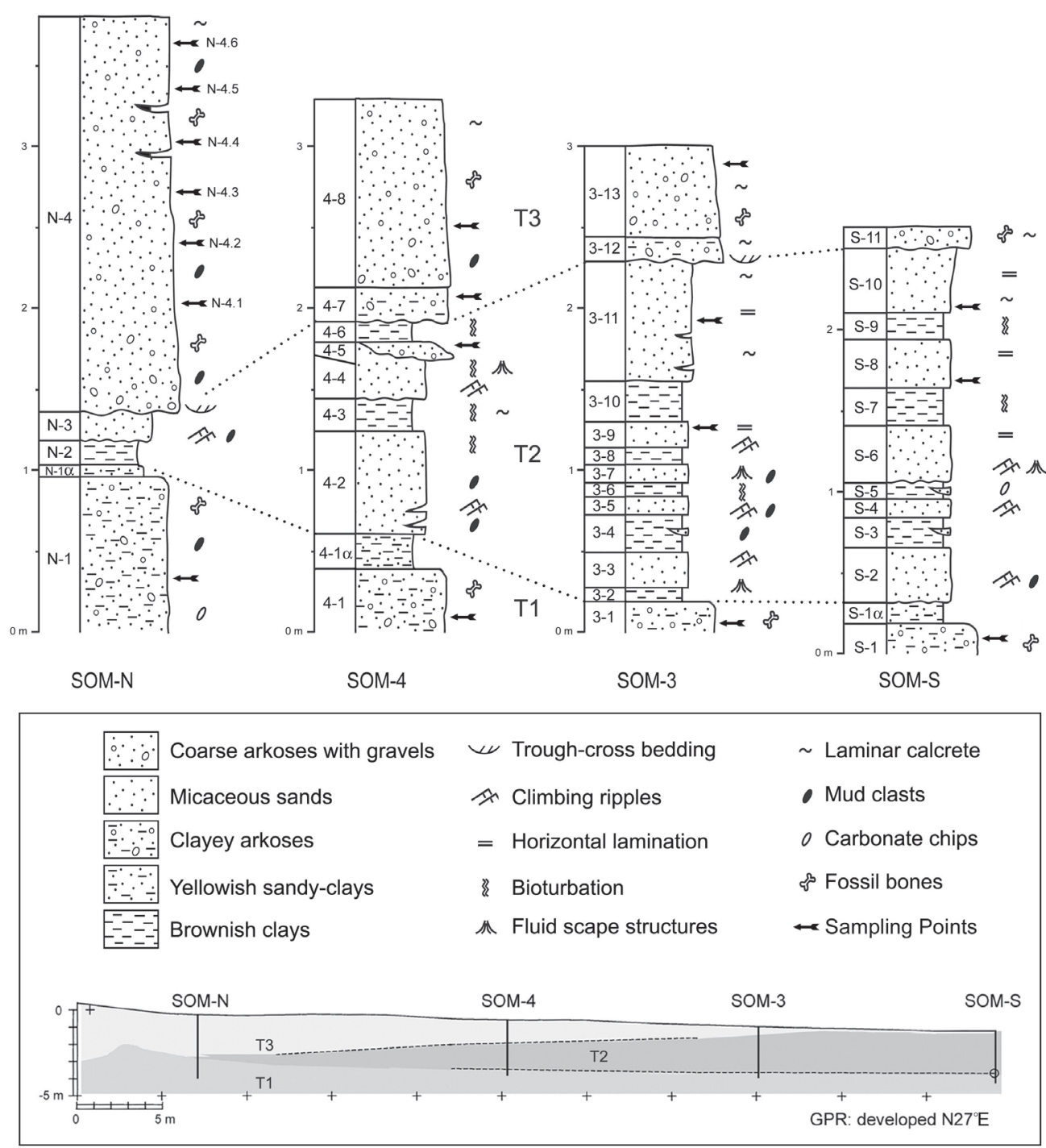

Fig. 2.- Stratigraphic sections of the Somosaguas palaeontological site and GPR profile N27E (modified from Fesharaki et al., 2007). Black arrows indicate the positions of the samples in each level.

tion of these sections is $666 \mathrm{~m}$. Geographic coordinates for the northermost and southernmost sections (Fesharaki et al., 2007) are: South Somosaguas $\left(40^{\circ} 25^{\prime} 53^{\prime \prime} \mathrm{N}, 3^{\circ} 47^{\prime} 16^{\prime \prime} \mathrm{W}\right)$ and North Somosaguas $\left(40^{\circ} 25^{\prime} 56^{\prime \prime} \mathrm{N}, 3^{\circ} 47^{\prime} 14^{\prime \prime} \mathrm{W}\right)$. These two stratigraphic sections are spaced around $60 \mathrm{~m}$ from each other. Three main units have been reported for the four sections (Mínguez Gandú, 2000; Fesharaki, 2005; Fig. 2).

A magnetostratigraphic study (Montes et al., 2006) carried out in the Madrid basin estimated for the Miocene Intermediate Unit (Megías et al., 1983) a sedimentation rate of aproximately 4.0 to $4.7 \mathrm{~cm} / \mathrm{ka}$. As the Somosaguas site shows an average thickness of $5 \mathrm{~m}$, a time-span of 105-125 ka can be estimated for the Somosaguas succession between the T1 and the top of the T3 unit (Domingo et al., 2009).

\subsection{Lower Unit (T1)}

This unit of variable thickness consists of poorly sorted clayey arkosic sands containing pebbles and reworked carbonate chips (Mínguez Gandú, 2000). Sands are matrix supported, mainly clayey (Fesharaki, 2005). According to
Fesharaki et al. (2007), this unit contains as much as $70 \%$ phyllosilicates (di and trioctahedral micas, beidellites and montmorillonites, kaolinite, and scarce illite/smectite mixed layers). The unit's microfossil content makes it one of the most productive sites in the Madrid Basin (López Martínez et al., 2000).

T1 has been interpreted as a mud flow deposit in a middistal arid alluvial fan (Mínguez Gandú, 2000) resembling the so-called "Madrid Facies" described by Riba (1959) and Benayas et al. (1960).

\subsection{Intermediate Unit (T2)}

The thickness of the T2 unit is highly variable $(25 \mathrm{~cm}$ to over $2 \mathrm{~m}$ ) and the unit pinches out and disappears towards the north and east of the area (Mínguez Gandú, 2000; Díez-Canseco et al., 2012). It is comprised of levels of arkosic sands very rich in micas interbedded with brownish muddy levels.

The sand fraction of the sandy levels ranges from very fine to medium grain size, and experiments a gradual drop in mica content towards the top of the unit. Climbing ripples are fre- 
quent and are replaced with high-energy parallel lamination towards the top (Mínguez Gandú, 2000; Fesharaki, 2005). This unit contains as much as $65 \%$ phyllosilicates (di and trioctahedral micas, beidellites and montmorillonites, kaolinite, and scarce illite/smectite mixed layers; Fesharaki et al., 2007). According to Mínguez Gandú (2000), its lithology is equivalent to that of the so-called "Guadalajara Facies" of the Madrid Basin.

Brownish muddy levels are comprised of clay and silt and show a small percentage of fine and medium sand grains and carbonate chips. These levels are homogenous and some of them show good lateral continuity. Their mineral composition indicates phyllosilicate contents of up to $80 \%$ (Fesharaki et al., 2007). In addition, they are the richest levels in organic matter but lack fossil remains (López Martínez et al., 2000).

This unit has been interpreted as sheet flood deposits originating in a distal arid alluvial fan, alternating with episodes of clay settling in shallow lake environments (Mínguez Gandú, 2000). Further interpretations include lacustrine deposits between coalescent alluvial fans or stream mouth lobes deposited in a shallow mass of stagnant water (Hernández Fernández et al., 2006; Díez-Canseco et al., 2012, and references therein).

\subsection{Upper Unit (T3)}

The thickness of this unit varies from a few centimetres in the South Somosaguas section to more than $3 \mathrm{~m}$ in the North Somosaguas section. Dipping $2^{\circ}$ to $3^{\circ}$ southwards the unit has an erosive base overlying $\mathrm{T} 2$ and shows cross-bedding locally close to the base (Minguez Gandú, 2000). It consists of coarse grained arkosic sands with a silty-clay matrix, interbedded with irregular clay levels. Phyllosilicates account for up to $60 \%$ of minerals. Their composition is similar to that described for the previous units (Fesharaki et al., 2007). Pebbles of granite, gneiss, quartzite and slate rock fragments (larger than $4 \mathrm{~mm}$ ) have been observed. At the top of the unit, laminar calcretes interbedded with clastic sediments occur (Mínguez Gandú, 2000; Fesharaki, 2005). This facies is similar to the so-called "Madrid Facies" (Riba, 1959; Benayas et al., 1960; Mínguez Gandú, 2000).

The unit has been interpreted as the outcome of debris flow deposits generated in an arid alluvial fan system (Mínguez Gandú, 2000). Élez (2005) carried out a Geographic Information System reconstruction of the layout of the fossil remains excavated between 1998 and 2004 field campaigns. This layout evidenced three distinct levels in T3 unit (which were named by this author T3-1, T3-2 and T3-3 from the bottom to the top) with high fossil remains concentration (mainly macrovertebrates), separated by levels with lower contents of fossils. Fesharaki (2005) also noticed that T3 have different levels with variable grain size distributions. This authors' and subsequent researchers (Domingo et al., 2009) suggest that these variations have been related to a multiepisodic depo- sitional process due to different pulses that produce several arkosic sedimentary bodies. To confirm this fact from a petrographic point of view we have selected 6 samples (named N-4.1 to N-4.6; see Fig. 2) that are representative of the three levels of high fossil contents and the other three levels with lower fossil concentration.

\section{Methods}

From the four stratigraphic sections, 18 samples representative of the three stratigraphic units (T1, T2, and T3) described by Fesharaki et al. (2007) were obtained (see Figs. $1 \mathrm{~b}$ and 2 for detailed stratigraphic locations).

Sand samples were washed with $10 \%$ diluted $\mathrm{H}_{2} \mathrm{O}_{2}$ to remove organic matter leading to a complete disaggregate fraction. The samples were then sieved to obtain the sandy fractions $(2-0.062 \mathrm{~mm})$. All samples were artificially cemented with epoxy resin and thin sectioned for microscopy observation and analysis. Each thin section was etched and stained using HF and Na-cobaltinitrite to help identify feldspars (Chayes, 1952).

Detrital modes in the sand fraction were quantified by petrographic analysis of thin sections using the integrated point counting method (Gazzi, 1966; Dickinson, 1970; Zuffa, 1985). This procedure combines the traditional method (Pettijohn, 1957) with the Gazzi-Dickinson method (Ingersoll et al., 1984). To avoid size-composition effects (Basu et al., 1975; Young, 1976; Zuffa, 1985) we only used the mediumsized sand fraction $(0.25$ to $0.50 \mathrm{~mm})$ for petrographic analysis. More than 400 points were counted on each slide. Twenty five petrographic classes were considered and grouped into the four main categories defined by Zuffa (1980): noncarbonate extrabasinal (NCE), carbonate extrabasinal (CE), noncarbonate intrabasinal (NCI) and carbonate intrabasinal (CI) (Tables 1, 2). In addition, 4 grades of plagioclase alteration were defined according to mineral transformation percentages $(<25 \%, 25-50 \%, 50-75 \%$ or $>75 \%)$.

Point counting of grains was performed using a modified version of the punctual-micrometric method (GlagolevChayes, 1933-1956): each mineral phase of a grain beneath the crosshairs was counted while freely moving the petrographic stage in successive trajectories following the main dimension of the slide.

In addition, we considered each of the four types of quartz grain (undulatory quartz, non-undulatory quartz, pollycrystalline quartz with 2-3 crystals per grain, pollycrystalline quartz with more than 3 crystals per grain) defined by Basu et al. (1975). Attention was also paid to other textural features of the quartz grains such as corrosion features (embayments), roundness, and fluid and solid inclusions (heavy minerals and micas).

Table 1 shows the petrographic classes and the main petrographic indices and parameters considered in this study. Point-count results are summarized in Table 2. 


\begin{tabular}{|c|c|c|c|c|c|}
\hline & PETROGRAPHIC CLASSES & $\begin{array}{c}\text { QFR } \\
\text { (Pettijohn } \\
\text { et al. 1972) }\end{array}$ & $\begin{array}{c}\text { QmFLt } \\
\text { (Dickinson } \\
\text { et al. 1983) }\end{array}$ & $\begin{array}{c}\text { QmKP } \\
\text { (Dickinson } \\
\text { 1985) }\end{array}$ & $\begin{array}{c}\mathrm{P} / \mathrm{F} \\
\text { (Dickinson } \\
1970 \text { ) }\end{array}$ \\
\hline \multirow[t]{20}{*}{ NCE } & Monocrystalline non-undulatory quartz (Qmnu) & Q & Qm & Qm & - \\
\hline & Monocrystalline undulatory quartz (Qmu) & Q & Qm & Qm & - \\
\hline & Polycrystalline quartz (2-3 crystals) $\left(\mathrm{Qp}_{2-3}\right)$ & Q & Qm & $\mathrm{Qm}$ & - \\
\hline & Polycrystalline quartz ( $>3$ crystals) $\left(\mathrm{Qp}_{>_{3}}\right)$ & Q & Qm & Qm & - \\
\hline & Quartz in plutonic or gneissic (phaneritic) rock fragment (Qrpg) & $\mathrm{R}$ & Qm & Qm & - \\
\hline & Quartz in meta-sedimentary rock fragment (Qrms) & $\mathrm{R}$ & Qm & Qm & - \\
\hline & K-feldspar (single crystal) (Ks) & $\mathrm{F}$ & $\mathrm{F}$ & $\mathrm{K}$ & $\mathrm{F}$ \\
\hline & Microcline (Kmic) & $\mathrm{F}$ & $\mathrm{F}$ & $\mathrm{K}$ & $\mathrm{F}$ \\
\hline & K-feldspar in phaneritic rock fragment (Krpg) & $\mathrm{R}$ & $\mathrm{F}$ & $\mathrm{K}$ & $\mathrm{F}$ \\
\hline & $\mathrm{K}$-feldspar in meta-sedimentary rock fragment $(\mathrm{Krms})$ & $\mathrm{R}$ & $\mathrm{F}$ & $\mathrm{K}$ & $\mathrm{F}$ \\
\hline & Plagioclase (single crystal) (Ps) & $\mathrm{F}$ & $\mathrm{F}$ & $\mathrm{P}$ & $\mathrm{P}$ \\
\hline & Plagioclase in phaneritic rock fragment (Prpg) & $\mathrm{R}$ & $\mathrm{F}$ & $\mathrm{P}$ & $\mathrm{P}$ \\
\hline & Shales and fillites (Shf) & $\mathrm{R}$ & $\mathrm{Lt}$ & - & - \\
\hline & Fine-grained Schists (Sch) & $\mathrm{R}$ & $\mathrm{Lt}$ & - & - \\
\hline & Unspecified chert (Ch) & Q & $\mathrm{Lt}$ & - & - \\
\hline & Muscovite (single crystal) (Ms) & - & - & - & - \\
\hline & Biotite (single crystal) (Bt) & - & - & - & - \\
\hline & Muscovite in phaneritic rock fragment (Msrpg) & $\mathrm{R}$ & - & - & - \\
\hline & Biotite in phaneritic rock fragment (Btrpg) & $\mathrm{R}$ & - & - & - \\
\hline & Dense minerals (unspecified) (Dm) & - & - & - & - \\
\hline \multirow[t]{4}{*}{ NCI } & Silty-clay soft grains, Intraclasts (In) & - & - & - & - \\
\hline & Quartz in intraclasts (Qnci) & - & Qm & Qm & - \\
\hline & K-feldspar in intraclasts (Knci) & - & $\mathrm{F}$ & $\mathrm{K}$ & $\mathrm{F}$ \\
\hline & Plagioclase in intraclasts (Pnci) & - & $\mathrm{F}$ & $\mathrm{P}$ & $\mathrm{P}$ \\
\hline CI & Micritic calcite (Mc) & - & $\mathrm{Lt}$ & - & - \\
\hline
\end{tabular}

Table 1.- Key to petrographic classes and recalculated parameters.

\begin{tabular}{|c|c|c|c|c|c|c|c|c|c|c|c|c|c|c|c|c|c|c|c|}
\hline \multirow{3}{*}{\multicolumn{2}{|c|}{ Petrographic Classes }} & \multicolumn{18}{|c|}{ Samples } \\
\hline & & \multicolumn{4}{|c|}{ T1 Unit } & \multicolumn{5}{|c|}{ T2 Unit } & \multicolumn{9}{|c|}{ T3 Unit } \\
\hline & & S-1 & $3-1$ & $4-1$ & $\mathrm{~N}-1$ & S-8 & S-10 & $3-9$ & $3-11$ & $4-5$ & $3-13$ & $4-7$ & $4-8$ & $\mathrm{~N}-4.1$ & $\mathrm{~N}-4.2$ & $\mathrm{~N}-4.3$ & N-4.4 & $\mathrm{N}-4.5$ & $5 \mathrm{~N}-4.6$ \\
\hline Qmnu & Monocrystalline non-undulatory quartz & 169 & 156 & 155 & 159 & 144 & 139 & 135 & 121 & 152 & 142 & 135 & 133 & 144 & 140 & 139 & 138 & 143 & 131 \\
\hline Qmu & Monocrystalline undulatory quartz & 38 & 39 & 43 & 42 & 42 & 43 & 38 & 37 & 50 & 33 & 39 & 34 & 35 & 34 & 33 & 31 & 29 & 24 \\
\hline Qp2-3 & Polycrystalline quartz (2-3 crystals) & 25 & 19 & 22 & 24 & 10 & 15 & 12 & 11 & 15 & 12 & 8 & 10 & 12 & 9 & 8 & 12 & 9 & 8 \\
\hline $\mathrm{Qp}>3$ & Polycrystalline quartz ( $>3$ crystals) & 16 & 17 & 17 & 14 & 14 & 9 & 10 & 10 & 9 & 8 & 10 & 5 & 9 & 11 & 6 & 3 & 5 & 3 \\
\hline Qrpg & Quartz in phaneritic rock fragment & 11 & 9 & 9 & 10 & 12 & 12 & 15 & 14 & 10 & 27 & 16 & 23 & 24 & 23 & 25 & 20 & 28 & 25 \\
\hline Qrms & Quartz in meta-sedimentry rock fragment & 1 & 0 & 2 & 2 & 2 & 2 & 2 & 1 & 1 & 2 & 2 & 2 & 1 & 2 & 1 & 0 & 1 & 1 \\
\hline $\mathrm{Ks}$ & K-feldspar (single crystal) & 100 & 90 & 94 & 99 & 86 & 94 & 88 & 77 & 91 & 83 & 75 & 79 & 81 & 85 & 79 & 79 & 84 & 81 \\
\hline Kmic & Microcline & 2 & 6 & 4 & 4 & 6 & 6 & 5 & 6 & 7 & 7 & 9 & 8 & 9 & 4 & 7 & 9 & 7 & 7 \\
\hline Krpg & K-feldspar in phaneritic rock fragment & 6 & 10 & 5 & 7 & 15 & 17 & 15 & 12 & 13 & 19 & 21 & 18 & 19 & 18 & 22 & 20 & 22 & 25 \\
\hline Krms & K-feldspar in meta-sedimentry rock fragment & 0 & 0 & 0 & 0 & 0 & 0 & 0 & 0 & 0 & 1 & 2 & 0 & 0 & 0 & 0 & 0 & 0 & 1 \\
\hline Ps & Plagioclase (single crystal) & 44 & 45 & 43 & 48 & 53 & 55 & 57 & 54 & 49 & 59 & 57 & 60 & 57 & 52 & 59 & 61 & 64 & 64 \\
\hline Prpg & Plagioclase in phaneritic rock fragment & 7 & 10 & 9 & 7 & 9 & 8 & 5 & 7 & 6 & 13 & 10 & 10 & 12 & 11 & 12 & 13 & 15 & 17 \\
\hline $\mathrm{Bt}$ & Biotite (single crystal) & 7 & 1 & 7 & 7 & 20 & 18 & 26 & 17 & 8 & 3 & 8 & 2 & 11 & 9 & 4 & 5 & 4 & 5 \\
\hline Ms & Muscovite (single crystal) & 5 & 7 & 3 & 3 & 2 & 7 & 6 & 6 & 10 & 6 & 5 & 5 & 6 & 6 & 4 & 4 & 6 & 5 \\
\hline Btrpg & Biotite in phaneritic rock fragment & 0 & 0 & 0 & 0 & 9 & 3 & 3 & 5 & 2 & 0 & 1 & 0 & 4 & 1 & 0 & 0 & 0 & 0 \\
\hline Msrpg & Muscovite in phaneritic rock fragment & 0 & 0 & 0 & 0 & 0 & 2 & 1 & 0 & 3 & 0 & 2 & 1 & 1 & 0 & 1 & 2 & 1 & 0 \\
\hline $\mathrm{Ch}$ & Unspecified chert & 0 & 0 & 0 & 0 & 2 & 0 & 0 & 1 & 0 & 0 & 0 & 0 & 0 & 0 & 0 & 2 & 1 & 0 \\
\hline Shf & Shales and fillites & 0 & 1 & 0 & 4 & 1 & 0 & 0 & 0 & 0 & 0 & 0 & 2 & 0 & 0 & 2 & 1 & 0 & 0 \\
\hline Sch & Schist & 2 & 1 & 2 & 6 & 1 & 1 & 2 & 2 & 1 & 4 & 3 & 1 & 1 & 1 & 4 & 3 & 4 & 2 \\
\hline Dm & Dense minerals (unspecified) & 0 & 0 & 1 & 0 & 0 & 0 & 0 & 0 & 1 & 0 & 0 & 0 & 0 & 0 & 0 & 1 & 0 & 0 \\
\hline In & Silty-clay soft grains, intraclasts & 8 & 7 & 6 & 3 & 6 & 6 & 7 & 7 & 2 & 7 & 9 & 7 & 10 & 7 & 7 & 6 & 12 & 6 \\
\hline Qnci & Quartz in intraclast & 1 & 5 & 5 & 11 & 4 & 9 & 7 & 7 & 5 & 7 & 7 & 8 & 8 & 3 & 3 & 0 & 2 & 1 \\
\hline Knci & $\mathrm{K}$-feldspar in intraclasts & 0 & 3 & 2 & 2 & 4 & 1 & 2 & 3 & 1 & 2 & 3 & 2 & 4 & 1 & 1 & 2 & 2 & 0 \\
\hline Pnci & Plagioclase in intraclasts & 1 & 0 & 2 & 4 & 4 & 2 & 1 & 1 & 4 & 2 & 2 & 1 & 3 & 5 & 1 & 0 & 4 & 1 \\
\hline $\mathrm{Mc}$ & Carbonates (micritic calcite) & 6 & 9 & 4 & 7 & 11 & 16 & 15 & 20 & 2 & 9 & 14 & 11 & 15 & 15 & 10 & 9 & 22 & 29 \\
\hline & TOTAL & 449 & 435 & 435 & 463 & 457 & 465 & 452 & 419 & 442 & 446 & 438 & 422 & 466 & 437 & 428 & 421 & 465 & 436 \\
\hline
\end{tabular}

Table 2.- Microscopy point counting data. 

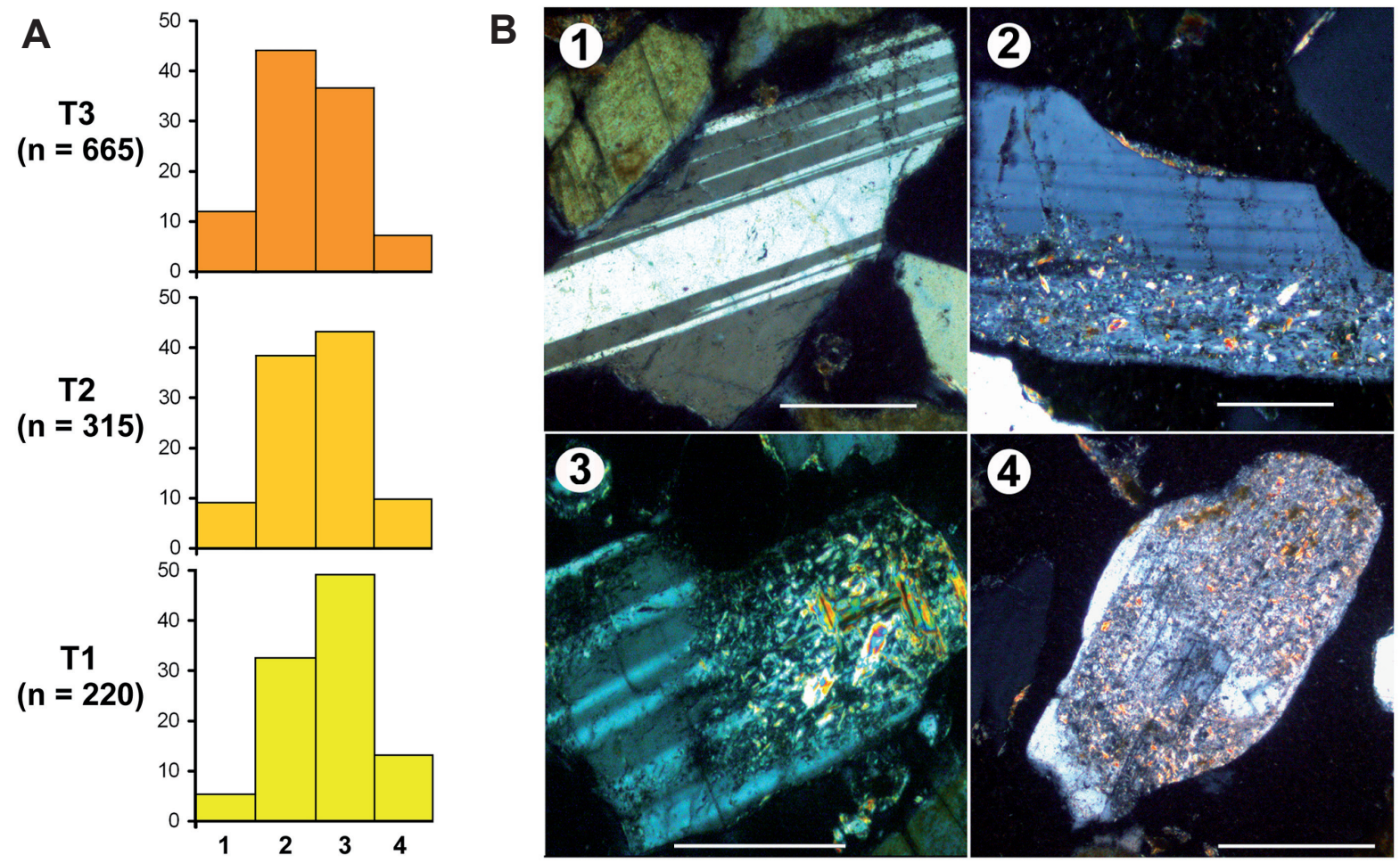

Fig. 3.- Grades of alteration of plagioclase grains. A) Histograms representing the variation in alteration detected in plagioclases from the three units $(\mathrm{T} 1, \mathrm{~T} 2, \mathrm{~T} 3)$ of the Somosaguas sedimentary sequence. Grade $1=0-25 \%$ alteration; grade $2=25-50 \%$ alteration; grade $3=50-75 \%$ alteration; grade $4=$ more than $75 \%$ alteration. B) Microphotographs of four grains representative of these alteration grades. Numbers in each photograph indicate the alteration grade (Scale bars $0.1 \mathrm{~mm}$ ).

of all grains, yet towards the top of $\mathrm{T} 3$ proportions reached $7 \%$. Based on their textural features, we interpreted these grains as intrabasinal origin grains $(\mathrm{CI})$.

\subsection{Modal Composition of Sands}

The modal composition of the sands' framework is represented in several ternary diagrams following the criteria of several authors: Pettijohn et al. (1972) (QFR); Dickinson et al. (1983) (QmFLt); Dickinson (1985) (QmKP) ; and Arribas et al. (2003), which is based on the quartz categories defined by Basu et al. (1975) (QmrQmoQp) (Table 4). These diagrams describe the main composition of sands and the textural types of some species as the quartz types $(\mathrm{Qnu}, \mathrm{Qu}$, $\mathrm{Qp}_{2-3}, \mathrm{Qp}_{>3}$ ) defined by Basu et al. (1975) and modified by Tortosa et al. (1991) for the Spanish Central System.

\begin{tabular}{|c|c|c|c|c|c|c|c|c|c|c|c|c|c|c|c|c|c|}
\hline \multirow{2}{*}{ Units } & \multirow{2}{*}{ Samples } & \multicolumn{16}{|c|}{ Petrographic Parameters } \\
\hline & & Q & $\mathrm{F}$ & $\mathrm{R}$ & Qm & $\mathrm{F}$ & $\mathrm{Lt}$ & $\mathrm{Qm}$ & $\mathrm{K}$ & $\mathrm{P}$ & Qmr & Qmo & $\mathrm{Qp}$ & Qnu & $\mathrm{Qu}$ & $\mathrm{Qp}_{2-3}$ & $\mathrm{Qp}_{>3}$ \\
\hline \multirow{9}{*}{$\mathrm{T} 3$} & $\mathrm{~N}-4.6$ & 42.7 & 39.1 & 18.3 & 49.4 & 50.1 & 0.5 & 49.6 & 29.3 & 21.1 & 78.9 & 14.5 & 6.6 & 82.9 & 15.2 & --- & 1.9 \\
\hline & $\mathrm{N}-4.5$ & 45.3 & 37.5 & 17.2 & 51.7 & 47.1 & 1.2 & 52.3 & 27.7 & 20.0 & 76.9 & 15.6 & 7.5 & 80.8 & 16.4 & --- & 2.8 \\
\hline & $\mathrm{N}-4.4$ & 47.2 & 37.8 & 15.0 & 51.8 & 46.7 & 1.5 & 52.6 & 28.4 & 19.1 & 75.0 & 16.8 & 8.2 & 76.2 & 17.1 & 6.6 & --- \\
\hline & $\mathrm{N}-4.3$ & 46.7 & 36.4 & 16.8 & 53.5 & 45.0 & 1.5 & 54.3 & 27.5 & 18.2 & 74.7 & 17.7 & 7.5 & 78.1 & 18.5 & --- & 3.4 \\
\hline & $\mathrm{N}-4.2$ & 49.6 & 36.1 & 14.3 & 55.6 & 44.1 & 0.3 & 55.8 & 27.1 & 17.1 & 72.2 & 17.5 & 10.3 & 75.7 & 18.4 & --- & 5.9 \\
\hline & N-4.1 & 48.9 & 35.9 & 15.2 & 55.6 & 44.2 & 0.2 & 55.7 & 27.0 & 17.2 & 72.0 & 17.5 & 10.5 & 76.6 & 18.6 & --- & 4.8 \\
\hline & $4-8$ & 47.2 & 38.1 & 14.8 & 54.3 & 44.9 & 0.8 & 54.7 & 27.2 & 18.1 & 73.1 & 18.7 & 8.2 & 77.3 & 19.8 & --- & 2.9 \\
\hline & $4-7$ & 49.2 & 36.2 & 14.6 & 54.4 & 44.9 & 0.8 & 54.8 & 27.8 & 17.4 & 70.3 & 20.3 & 9.4 & 73.4 & 21.2 & --- & 5.4 \\
\hline & $3-13$ & 47.6 & 36.3 & 16.1 & 54.9 & 44.2 & 1.0 & 55.4 & 26.9 & 17.7 & 72.8 & 16.9 & 10.3 & 77.6 & 18.0 & --- & 4.4 \\
\hline \multirow{5}{*}{$\mathrm{T} 2$} & $4-5$ & 55.3 & 35.9 & 8.8 & 58.5 & 41.3 & 0.2 & 58.6 & 27.1 & 14.3 & 67.3 & 22.1 & 10.6 & 72.0 & 23.7 & --- & 4.3 \\
\hline & $3-11$ & 50.3 & 38.3 & 11.5 & 55.2 & 44.0 & 0.8 & 55.7 & 27.1 & 17.2 & 67.6 & 20.7 & 11.7 & 72.0 & 22.0 & --- & 6.0 \\
\hline & $3-9$ & 50.3 & 38.7 & 11.1 & 55.6 & 43.9 & 0.5 & 55.9 & 28.1 & 16.1 & 69.2 & 19.5 & 11.3 & 73.8 & 20.8 & --- & 5.5 \\
\hline & S-10 & 50.7 & 38.2 & 11.1 & 55.4 & 44.3 & 0.2 & 55.6 & 28.6 & 15.8 & 67.5 & 20.9 & 11.7 & 72.8 & 22.5 & --- & 4.7 \\
\hline & S-8 & 52.2 & 35.7 & 12.1 & 55.7 & 43.3 & 1.0 & 56.3 & 27.4 & 16.3 & 68.6 & 20.0 & 11.4 & 72.0 & 21.0 & --- & 7.0 \\
\hline \multirow{4}{*}{$\mathrm{T} 1$} & N-1 & 56.1 & 35.4 & 8.5 & 59.1 & 38.6 & 2.3 & 60.5 & 25.9 & 13.6 & 66.5 & 17.6 & 15.9 & 74.0 & 19.5 & --- & 6.5 \\
\hline & $4-1$ & 58.5 & 34.8 & 6.7 & 61.1 & 38.4 & 0.5 & 61.4 & 25.5 & 13.1 & 65.4 & 18.1 & 16.5 & 72.1 & 20.0 & --- & 7.9 \\
\hline & $3-1$ & 57.3 & 35.0 & 7.7 & 59.6 & 39.9 & 0.5 & 59.9 & 26.7 & 13.4 & 67.5 & 16.9 & 15.6 & 73.6 & 18.4 & --- & 8.0 \\
\hline & S-1 & 58.9 & 34.7 & 6.4 & 61.7 & 37.8 & 0.5 & 62.0 & 25.7 & 12.4 & 68.1 & 15.3 & 16.5 & 75.8 & 17.0 & --- & 7.2 \\
\hline
\end{tabular}

Table 4.- Recalculated petrographic parameters for the Somosaguas sands. Qmr, Qmo, Qp are used sensu Arribas et al. (2003). 


\section{Results}

\subsection{Grain types}

Non Carbonate Extrabasinal grains (NCE):

These grains were by far the most abundant and included quartz, feldspar, rock fragments, heavy minerals and micas.

Quartz: In all samples, non-undulatory monocrystalline quartz grains $(30.7 \%$ to $38.5 \%)$ were clearly dominant over undulatory quartz grains $(5.6 \%$ to $11.4 \%)$. In addition, monocrystalline quartz varieties were more abundant than pollycrystalline varieties (up to sevenfold in quantity) in all the samples examined. Most polycrystalline quartz grains showed between 2 and 5 crystals per grain. Polycrystalline quartz grains with more than 10 crystals per grain usually showed a preferred orientation of crystals. Included in this category, were all quartz crystals comprising phaneritic rock fragments.

About $10 \%$ of the quartz crystals had mica or heavy mineral inclusions (mainly tourmaline, rutile and apatite, but also opaques, garnet and zircon). The proportions of moderately rounded quartz grains were practically constant at less than $10 \%$ throughout all the stratigraphic sections.

Feldspars: This category included single crystals of Kfeldspar, microcline and plagioclase, as well as potassium feldspar and plagioclase included in intraclasts, phaneritic rock fragments, and sedimentary rock fragments (meta-arenites). Feldspars with cross-hatched twins were assigned to the microcline variety.

Among the feldspars, K-feldspar grains predominated over alkaline ones, and orthoclase crystals over the microcline variety. Microcline grain proportions remained fairly constant in all the stratigraphic sections, never exceeding $10 \%$.

From base to top of the stratigraphic sections, we observed a significant increase in slightly altered grains $(<25 \%$ alteration) and a decrease in the most altered grains ( $>75 \%$ alteration) (see Fig. 3a and Table 3). The extent of plagioclase alteration in a single sample was highly variable. Slightly altered crystals coexisted with those completely replaced by phyllosilicates. In some crystals preferential alteration on weakness planes, fractures and twin planes could be observed (Fig. 3b).

Rock fragments: We considered as rock fragments all aggregates of two or more mineral species, none of which comprised $90 \%$ of the section. Rock fragments bearing crystals smaller than $0.062 \mathrm{~mm}$ were recorded as "labile" (L) according to the criteria of Dickinson (1970), and were usually aphanitic fragments of phyllites, slates and schists. Chert fragments are also assigned to this group (L) (Dickinson, 1970; Dickinson et al., 1983; Zuffa, 1980). Rock fragments composed of crystalline units larger than $0.062 \mathrm{~mm}$ (phaneritic rock fragments, $\mathrm{R}$ ) were interpreted as the constituent minerals of the rock fragment (Table 2). This petrographic class mainly includes phaneritic rock fragments (granites and gneisses). Also included in this category were fragments of metasedimentary rocks (Lms).

\begin{tabular}{clcccc}
\hline \multirow{2}{*}{ Units } & \multirow{2}{*}{ Samples } & \multicolumn{4}{c}{ Grades of plagioclase alteration } \\
\cline { 3 - 6 } & & 1 & 2 & 3 & 4 \\
\hline \multirow{6}{*}{ T3 -4.6} & 15 & 43 & 20 & 4 \\
& N-4.5 & 12 & 40 & 25 & 6 \\
& N-4.4 & 9 & 33 & 28 & 4 \\
& N-4.3 & 7 & 30 & 30 & 5 \\
& N-4.2 & 5 & 26 & 30 & 7 \\
& N-4.1 & 5 & 29 & 32 & 6 \\
& $4-8$ & 10 & 33 & 24 & 4 \\
& $4-7$ & 8 & 29 & 25 & 7 \\
& $3-13$ & 9 & 34 & 26 & 5 \\
\hline \multirow{6}{*}{ T2 } & $4-5$ & 6 & 20 & 24 & 9 \\
& $3-11$ & 5 & 25 & 27 & 5 \\
& $3-9$ & 6 & 25 & 27 & 5 \\
& S-10 & 6 & 25 & 28 & 6 \\
& S-8 & 6 & 26 & 29 & 5 \\
\hline \multirow{6}{*}{ T1 } & N-1 & 3 & 20 & 29 & 7 \\
& $4-1$ & 3 & 17 & 26 & 8 \\
& $3-1$ & 3 & 18 & 27 & 7 \\
& S-1 & 3 & 16 & 26 & 7 \\
\hline
\end{tabular}

Table 3.- Number of plagioclases in each sample grouped into the defined four stages of alteration (phyllosilicate transformation). Grade $1(0-25 \%)$ refers to an altered surface area in a plagioclase section under $25 \%$ and so on for grades 2 (25-50\%), 3 (50-75\%) and $4(75-100 \%)$. Grade 4 indicates very altered grains or those that have passed completely to phyllosilicates.

Granite and gneiss rock fragments clearly predominated over other rock fragments. In general, phaneritic rock fragment contents increased from base to top in the stratigraphic sequence. These fragments mostly contained few crystals (2-5).

Low and medium-rank metamorphic rock fragments (Fig. $4 a)$ were unevenly distributed, usually representing less than $5 \%$ of the total number of grains (Table 2 ).

Meta-sedimentary rock fragments appeared in low but constant proportions throughout the levels examined. Crystal sizes are highly variable in some fragments (Fig. 4b).

Micas: To this group, we assigned individual crystals of biotite and muscovite as well as crystals of these minerals in phaneritic rock fragments. Unit T2 showed the highest mica content followed by T3 and then T1. In some samples from $\mathrm{T} 2$, micas accounted for up to $50 \%$ of all grains.

\section{Non Carbonate Intrabasinal grains (NCI)}

This category included small silty clay aggregates (intraclasts) incorporating quartz, feldspar and mica grains. At all levels and in all stratigraphic sections intraclasts represented less than $3 \%$ of all grains. Within the aggregates, detrital grains larger than $0.062 \mathrm{~mm}$ were frequently observed.

\section{Carbonate grains $(C)$}

Assigned to this class, were small micrite grains of calcite composition of rounded irregular shapes. Frequently, quartz and feldspar grains were coated with micritic material. Carbonate micrite grains also showed clay minerals inclusions (Fig. 4c). Commonly, these grains represented less than $4 \%$ 

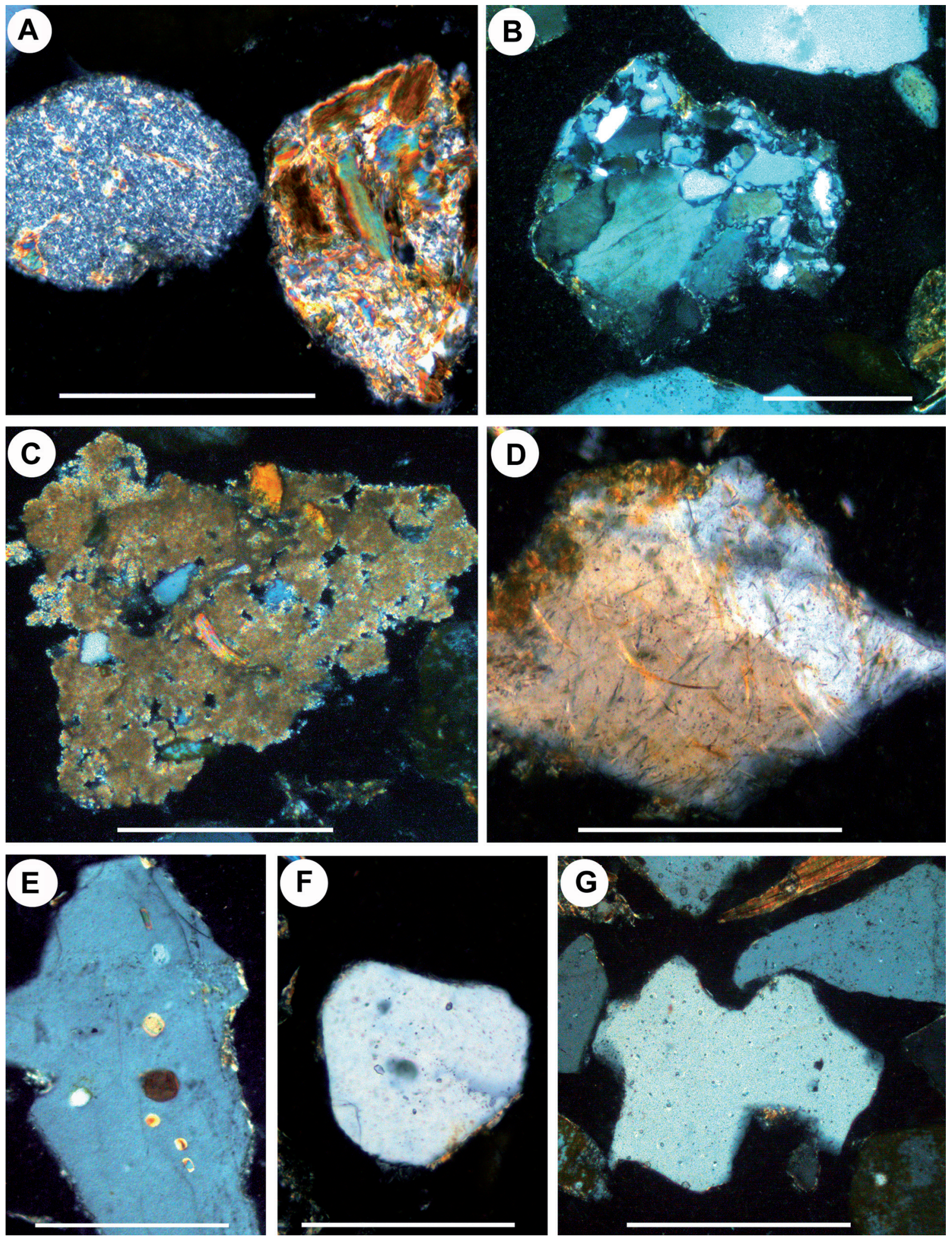

Fig. 4.- Photomicrographs (crossed polars) of the components of the Somosaguas sediments. A) Metamorphic rock fragments; B) Metasedimentary rock fragment showing highly variable crystal sizes; C) Carbonate micrite grain with detritus and clay mineral inclusions; D) Quartz grain with rutile needle inclusions; E) Quartz grain with mica inclusions; F) Rounded quartz grain; G) Embayed quartz grain (Scale bars $0.25 \mathrm{~mm}$ ). 
The main composition shown in the QFR diagram (Fig. 5a; Pettijohn et al., 1972) indicates an arkosic sediment, exhibiting the prevalence of quartz (Q) and feldspar (F) grains over total rock fragments (R), that does not exceed $20 \%$ in the medium-size sand fraction examined. These fragments are more abundant in the T3 unit, and coincide with the levels showing the higher feldspar contents. Sandy levels with lower feldspar contents occur in T1, also corresponding to levels with high quartz proportions $(\sim 60 \%)$. Sand composition from T1 to T3 clearly shows a trend towards increasing $\mathrm{F}$ and $\mathrm{R}$ contents.

In the QmFLt diagram (Fig. 5b; Dickinson, 1970), the petrofacies of the sand deposits appear quartz feldespathic in nature with provenance types related to geotectonic settings described by Dickinson et al. (1983) as transitional between "transitional continental" and "basement uplift". The samples are mainly plotted on the QmF side and show scarce amounts of labile rock fragments. From T1 to T3, a clear trend is observed towards higher feldspar contents in the uppermost sandy levels (Fig. 5b). The diagnosis of the geotectonic environment is straightforward, as the deposits are related to "basement uplift" environments created in response to the activity of the Central System during the middle Miocene (Calvo et al., 1989a,b; De Vicente et al., 1996).

The QmKP diagram (Fig. 5c; Dickinson, 1985) reveals clear differences in the feldspar contents of the three units, showing a similar trend to that indicated by the diagrams described above. Thus, average K-feldspar contents increase from $26 \%$ in $\mathrm{T} 1$ to $27.7 \%$ in $\mathrm{T} 3$, being this increase most evident at the top of the sequence. Plagioclase (P) grains show a greater increase with average contents of 13.1, 15.9 and 18.4 observed for T1, T2 and T3, respectively.

The QmrQmoQp diagram (Fig. 5d; Basu et al., 1975; Arribas et al., 2003) shows faint variations that could reflect discrete differences in source area composition. T1 appears separated from the other two units due to its greater polycrystalline quartz (Qp) contents, while T2 and T3 differ in that non-undulatory quartz (Qmr) grains predominate over undulatory quartz (Qmo) grains in $\mathrm{T} 3$.

In the Qnu, Qu, $\mathrm{Qp}_{2-3}, \mathrm{Qp}_{>3}$ rhombic diagram (Fig. 6; Basu et al., 1975; Tortosa et al., 1991), samples of the Somosaguas sediments are plotted in the plutonic-metamorphic high grade provenance field. Samples of T2 and T3 sediments show a tendency to move away from the $\mathrm{Qp}_{2-3}$ apex and the $\mathrm{T} 3$ data tend to approach the Qnu vertex.
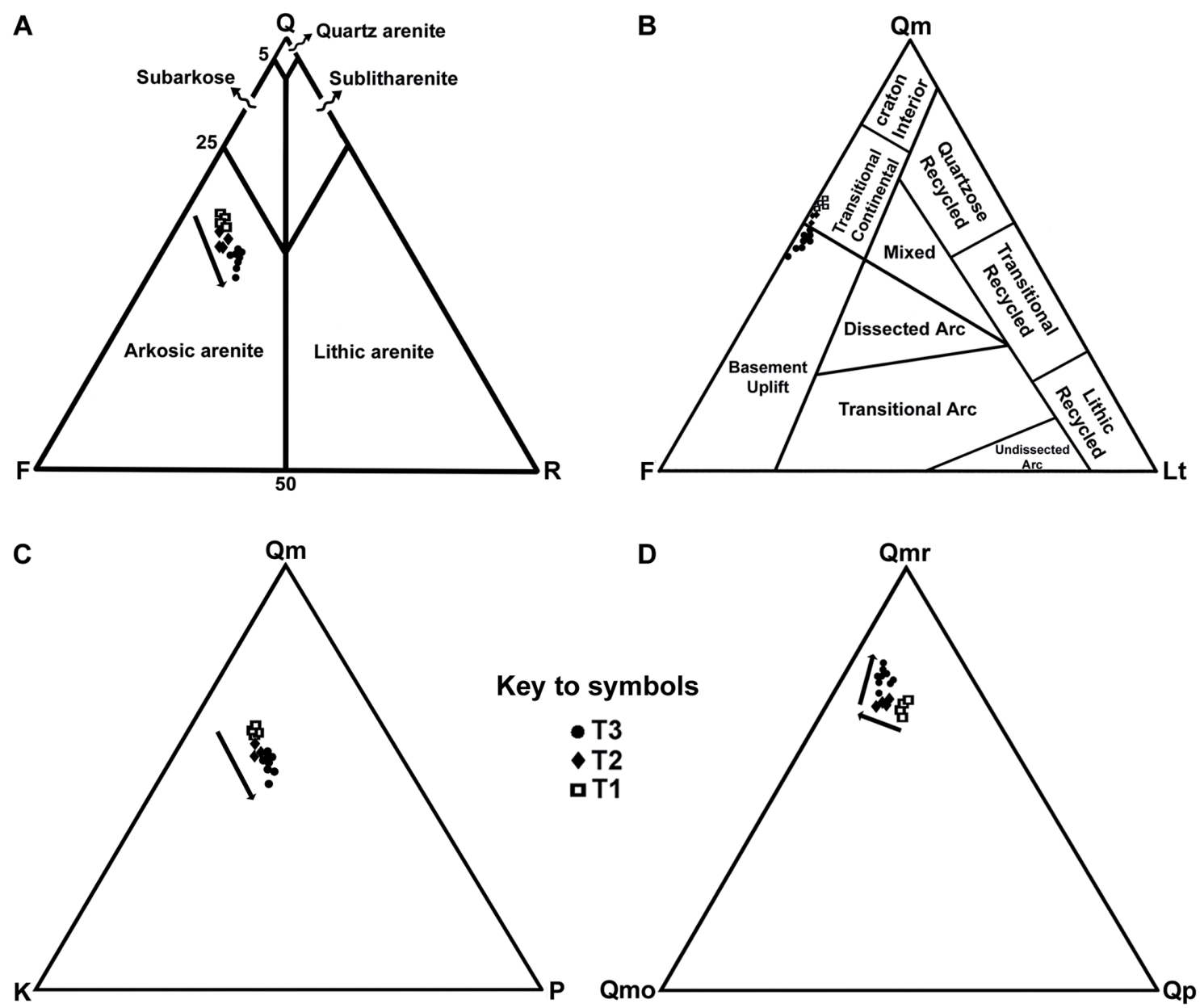

Fig. 5.- Ternary plots describing the composition of the Somosaguas sands. A) QFR diagram (Pettijohn et al., 1972); B) QmFLt diagram (Dickinson, 1970); C) QmKP diagram (Dickinson, 1985); D) QmrQmoQp diagram (Basu et al., 1975; Arribas et al., 2003 ). 


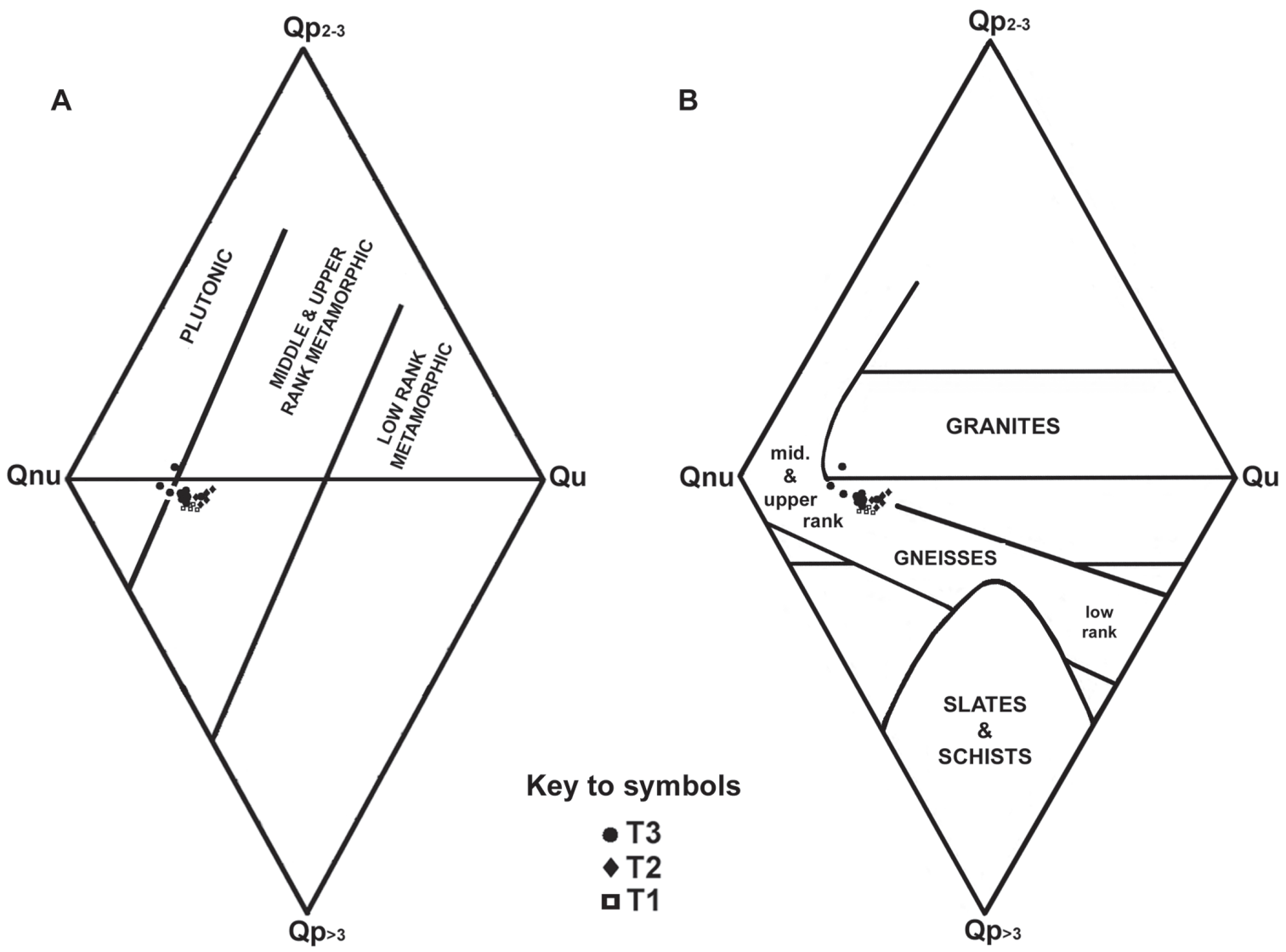

Fig. 6.- Point-count data derived from a medium-grained quartz population plotted on the diamond-shaped provenance-discrimination diagrams of: A) Basu et al. (1975); B) Tortosa et al. (1991); Qnu = non-undulatory monocrystalline quartz; Qu = undulatory monocrystalline quartz; $\mathrm{Qp}_{2-3}=$ polycrystalline quartz with 2-3 crystals; $\mathrm{Qp}_{>3}=$ polycrystalline quartz with more than 3 crystals.

\subsection{Petrographic parameters}

To assess changes in sand composition, we established a set of indices (Table 5). These indices indicate the maturity of a deposit (Qp + Qm/ F + R; Qp/ F + R), the presence of metamorphic rocks in the source area $(\mathrm{Qmr} / \mathrm{Qm} ; \mathrm{Qp} / \mathrm{Qt})$, and are also sensitive to climate (Plagioclase/K-Feldspar; P/F) (Dickinson, 1970; Basu, 1976; Suttner and Dutta, 1986). Bivariate logratio of Quartz/Feldspar versus Quartz/Rock fragments $(\ln \mathrm{Q} / \mathrm{F}$ vs. $\ln \mathrm{Q} / \mathrm{R})$ plots are used to determine climate

\begin{tabular}{|c|c|c|c|c|c|c|c|c|c|}
\hline \multirow{2}{*}{ Units } & \multirow{2}{*}{ Samples } & \multicolumn{8}{|c|}{ Petrographic Indexes } \\
\hline & & $\mathrm{Qp}+\mathrm{Qm} / \mathrm{F}+\mathrm{R}$ & $\mathrm{Qp} / \mathrm{F}+\mathrm{R}$ & $\mathrm{Q} / \mathrm{F}$ & $\mathrm{Q} / \mathrm{R}$ & $\mathrm{Qmr} / \mathrm{Qm}$ & $\mathrm{Qp} / \mathrm{Qt}$ & $\mathrm{P} / \mathrm{F}$ & $\mathrm{Lm} / \mathrm{Rt}$ \\
\hline \multirow{9}{*}{$\mathrm{T} 3$} & $\mathrm{~N}-4.6$ & 0.70 & 0.05 & 1.10 & 2.35 & 0.85 & 0.07 & 0.42 & 0.03 \\
\hline & $\mathrm{N}-4.5$ & 0.80 & 0.06 & 1.22 & 2.61 & 0.83 & 0.08 & 0.42 & 0.05 \\
\hline & $\mathrm{N}-4.4$ & 0.90 & 0.07 & 1.22 & 3.02 & 0.82 & 0.08 & 0.40 & 0.07 \\
\hline & $\mathrm{N}-4.3$ & 0.90 & 0.07 & 1.29 & 2.82 & 0.81 & 0.08 & 0.40 & 0.09 \\
\hline & $\mathrm{N}-4.2$ & 1.00 & 0.10 & 1.34 & 3.52 & 0.80 & 0.10 & 0.39 & 0.02 \\
\hline & $\mathrm{N}-4.1$ & 1.00 & 0.10 & 1.35 & 3.35 & 0.80 & 0.11 & 0.39 & 0.02 \\
\hline & $4-8$ & 0.90 & 0.07 & 1.27 & 3.33 & 0.80 & 0.08 & 0.40 & 0.05 \\
\hline & $4-7$ & 1.00 & 0.09 & 1.36 & 3.49 & 0.78 & 0.09 & 0.39 & 0.05 \\
\hline & $3-13$ & 0.90 & 0.09 & 1.31 & 3.06 & 0.81 & 0.10 & 0.40 & 0.06 \\
\hline \multirow{5}{*}{$\mathrm{T} 2$} & $4-5$ & 1.30 & 0.13 & 1.52 & 6.42 & 0.75 & 0.11 & 0.35 & 0.03 \\
\hline & $3-11$ & 1.00 & 0.12 & 1.32 & 4.43 & 0.77 & 0.12 & 0.39 & 0.05 \\
\hline & $3-9$ & 1.10 & 0.11 & 1.32 & 4.70 & 0.78 & 0.11 & 0.36 & 0.05 \\
\hline & S-10 & 1.10 & 0.12 & 1.36 & 4.78 & 0.76 & 0.12 & 0.36 & 0.02 \\
\hline & S-8 & 1.10 & 0.12 & 1.40 & 4.20 & 0.77 & 0.11 & 0.37 & 0.04 \\
\hline \multirow{4}{*}{$\mathrm{T} 1$} & $\mathrm{~N}-1$ & 1.30 & 0.20 & 1.59 & 6.94 & 0.79 & 0.16 & 0.35 & 0.28 \\
\hline & $4-1$ & 1.40 & 0.23 & 1.67 & 8.96 & 0.78 & 0.16 & 0.34 & 0.07 \\
\hline & $3-1$ & 1.30 & 0.21 & 1.64 & 7.61 & 0.80 & 0.16 & 0.34 & 0.07 \\
\hline & S-1 & 1.40 & 0.24 & 1.69 & 9.22 & 0.81 & 0.17 & 0.33 & 0.07 \\
\hline
\end{tabular}

Table 5.- Numerical values of the petrographic indices applied to the point counting data. 


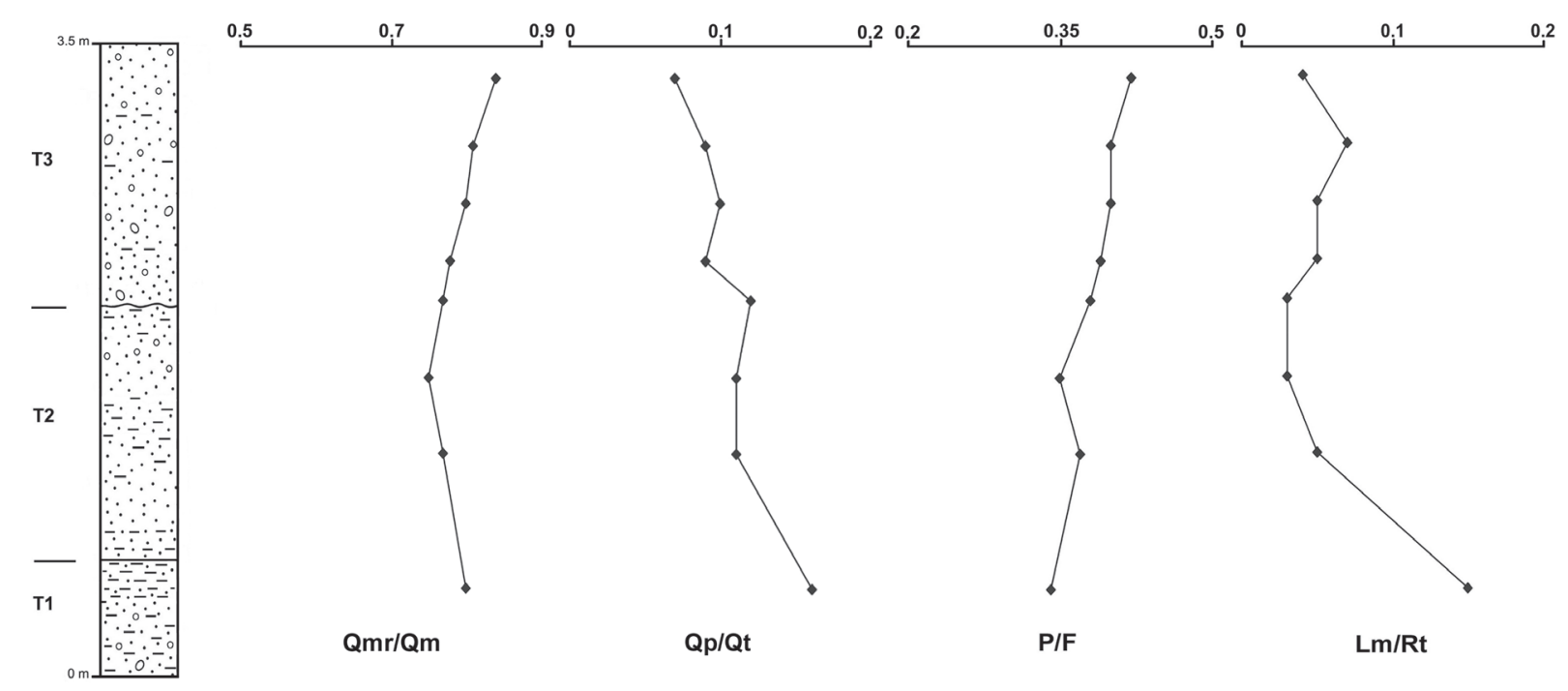

Fig. 7.- Vertical composition trends indicated by the indices Qmr/Qm; Qp/Qt; P/F and Lm/Rt. Represented values are averages for similar levels (samples) of the T1, T2 and T3 units in a synthetic stratigraphic section representative of the Somosaguas area.

and physiographic conditions (Weltje et al., 1998). Another indicator used in this study was the ratio of Schist plus Slate (labile) to total rock fragments $(\mathrm{Lm} / \mathrm{Rt})$.

Figure 7 provides the values of some of these indices for the different units of a synthetic stratigraphic section. The Qmr/ Qm index shows a decreasing pattern across the T1 and T2 units and then increases, especially towards the top of the sequence (T3). Qp/Qt and P/F indices show opposite trends: the former decreases upwards through the section and the later increases in the same direction. Low rank metamorphic rock fragments (labile) expressed in relation to total rock fragments $(\mathrm{Lm} / \mathrm{Rt}$ ) are low for units $\mathrm{T} 2$ and $\mathrm{T} 3$ and slightly higher for T1. The Qp $+\mathrm{Qm} / \mathrm{F}+\mathrm{R}$ index (Table 5) was low for all units and levels, although it can be observed that this index decreases from T1 (1.4) to T3 (0.7). The Qp/ F + R index displays extremely low values, but like the previous index, values decrease from the base of $\mathrm{T} 1$ to the top of the stratigraphic sections (T3). Both indices were used to represent Suttner and Dutta's (1986) diagram for climate analysis (Fig. 8). All the indices and parametres used in this study show differences between the six samples (Fig. 2) collected from the T3 unit (Tables 3, 4, 5; Fig. 7). All the variations and graphs of figures 7 and 8 will be explained in the discussion section.

\section{Discussion}

\subsection{Provenance and geotectonic setting}

The average composition of the Somosaguas sands, taking into account the enrichment in quartz grains and reduction in rock fragment grains during transport (Table 4, Fig. 5b), resembles that of the mixed granite-gneiss source areas of the Central System characterized by Tortosa et al. (1988). Comparing these data with the average values obtained by Palomares and Arribas (1993) for different mixed source ar- eas in the Central System, our results are consistent with areas defined as mixtures of granites (about 60\%) and gneisses (about $40 \%$ ), though with some influence of medium-low grade metamorphic materials as indicated by the labile rock fragments observed (Table 2). In addition, the presence in Somosaguas of rock fragments composed of oriented quartz and mica as well as unstable polycrystalline quartz (Young, 1976), showing more than 10 crystals in some cases, indicates the existence of low grade metamorphic materials in the source area.

In the sediments examined, non-undulatory quartz predominated over undulatory quartz, and we detected a smaller percentage of polycrystalline quartz $(\mathrm{Qnu} / \mathrm{Qu} / \mathrm{Qp} 2-3 / \mathrm{Qp}>3=$ $71 / 18 / 6 / 5$ ), suggesting a gneissic-plutonic provenance (Basu et al., 1975; Tortosa et al., 1991). These last authors argued that this distinction is not entirely reliable in discerning between the larger contribution of a granitic versus a gneissic origin, as this depends on factors related to each single pluton. While sand samples of units $\mathrm{T} 1$ and $\mathrm{T} 2$ are plotted in middle-upper rank metamorphic fields (gneisses), samples of T3 seemed to be more related to plutonic (granites) sources (Table 2, Fig. 6).

Among the polycrystalline quartz grains, a prevalence of grains with 2 to 5 crystals, as well as rock fragments showing less than 5 crystals supports an origin for the Somosaguas sediments in plutonic source areas over high grade metamorphic sources. However, among the feldspars, K-feldspars outnumbered plagioclases. This distribution approaches what we might expect for a gneissic provenance area (Palomares and Arribas, 1993). The low proportion of zoned plagioclases observed by point-counting (Tortosa et al., 1989) is consistent with this notion. The gradual decrease in the Qp/Qt rate (Fig. 7) may be indicative of a slightly greater metamorphic contribution at the base of the sequence (T1). The Qmr/Qm ratio varies slightly suggesting that $\mathrm{T} 1$ and $\mathrm{T} 2$ receive more 
A

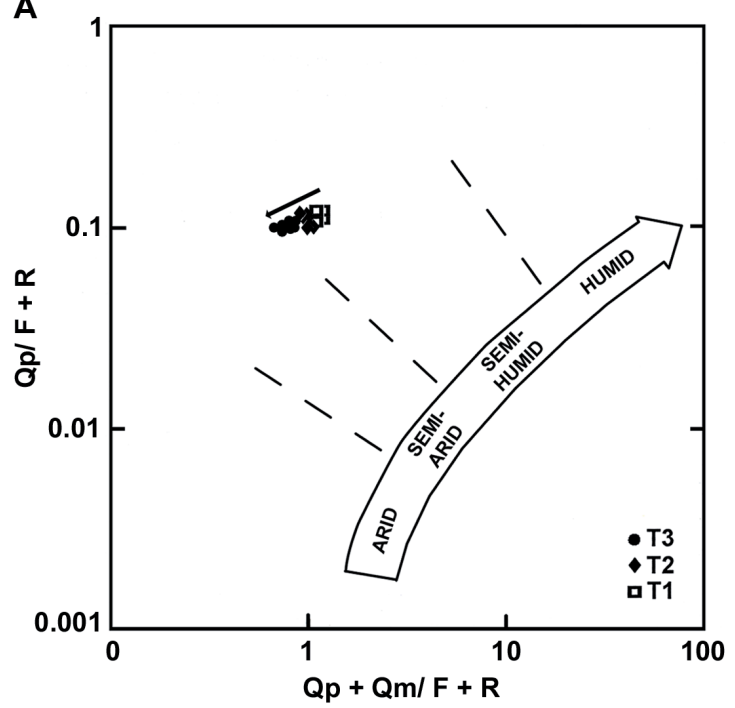

C

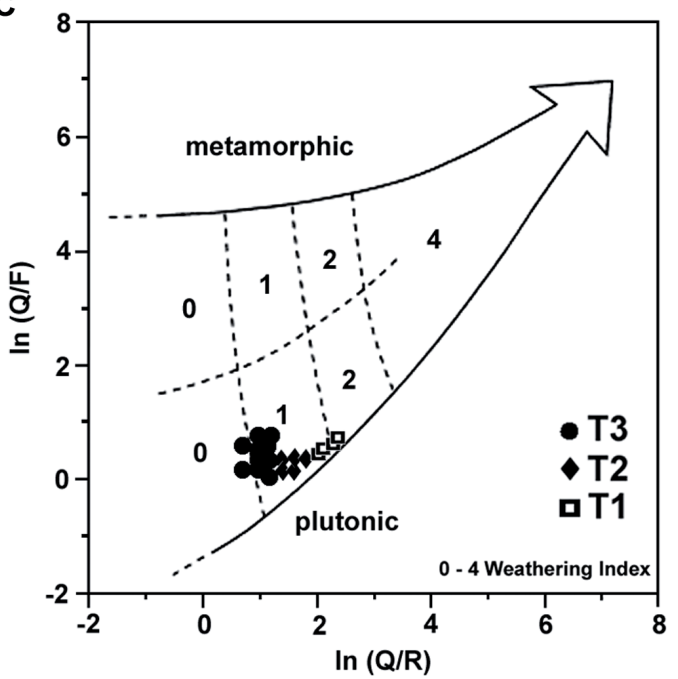

B

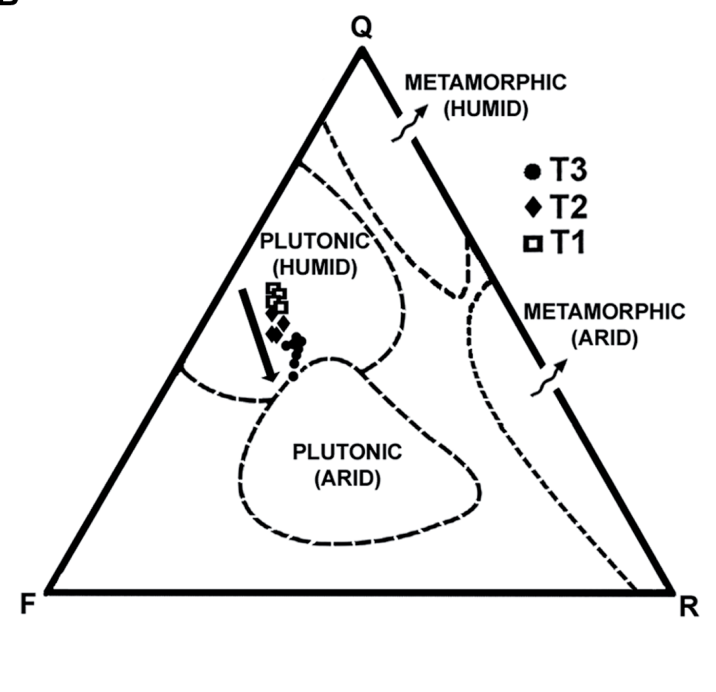

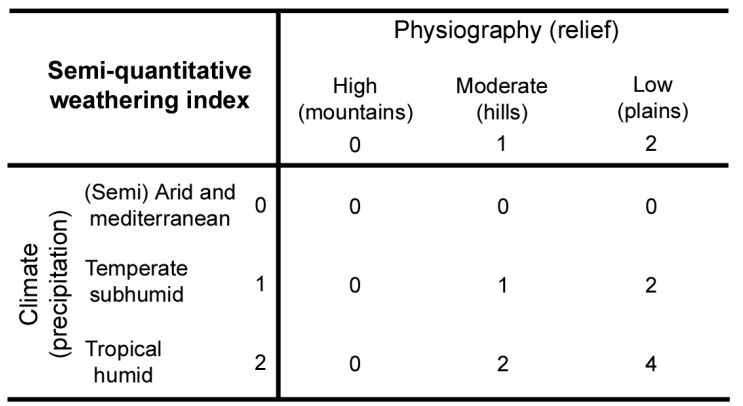

Fig. 8.- Diagrams used for the palaeoclimate inferences. A) Qp + Qm/ F + R versus $\mathrm{Qp} / \mathrm{F}+\mathrm{R}$ log-diagram (after Suttner and Dutta, 1986); B) The effect of source rock and climate on the composition of the Somosaguas samples was determined using Suttner's et al. (1981) diagram; C) Semi-quantitative weathering index based on semi-quantitative estimates for climate and relief (Weltje, 1994).

from metamorphic source areas than T3. The P/F index (Table 5), used by several authors as a provenance indicator (Dickinson, 1970; Ingersoll, 1978), increases slightly towards the top of the Somosaguas sedimentary sequence. This increase could indicate the prevalence of granitoids and gneisses over low-grade metamorphic rocks towards the T3 unit (Fig. 7). Data on mineral inclusions within quartz grains can provide additional information. The presence at all levels of quartz crystals with mica inclusions (Fig. 4e) is indicative of source areas with metamorphic influence (gneissic and schistose; Tortosa et al., 1988) while the presence of quartz grains with rutile needles inclusions (Fig. 4d) suggests granulite facies rocks at the source area (Mason, 1990; Di Giulio et al., 1999). The presence of white mica in all the units indicates a granite provenance, mainly one of peraluminous granitoids ( $\mathrm{Di}$ Giulio et al., 1999).

Our observation of labile rock fragments (slates and schists) and fragments of meta-sedimentary and phaneritic rocks (Table 2) indicates a mixed composition source area (Mack, 1981). However, as several authors have suggested (Palomares and Arribas, 1993; Le Pera and Arribas, 2004), the abundance of these grains in the sediments is not directly related to their abundance in the source area. Even when each lithology have a different Sand Generation Index (Palomares and Arribas, 1993; Arribas et al., 2000; Arribas and Tortosa, 2003), we can define the extent of intervention of each lithology in the final mixture based on other features. For example, a drop is produced in the $\mathrm{Lm} / \mathrm{Rt}$ index indicating a smaller contribution of low-grade metamorphic rocks towards the top of the sedimentary succession. This finding may be explained by gradual loss of the metamorphic cover in the source area.

Source area lithology is highly dependent on the geotectonic context in which it originated (Dickinson, 1985, 1988). Modal data for the Somosaguas samples plotted on the QmFLt diagram (Dickinson et al., 1983) appear between the "transitional continental" and "basement uplift" fields and 
display a composition trend from $\mathrm{T} 1$ to $\mathrm{T} 3$ towards the "basement uplift" field (Fig. 5c). These intermediate or undefined situations were identified by Mack (1984), who related the presence of quartzo-feldespathic rock fragments, such as those observed in the Somosaguas sediments, with granitegneiss source areas in basement uplift contexts and their subsequent erosion. According to Ingersoll and Suczek (1979), the prevalence of monocrystalline quartz, feldspar and mica suggests an origin for the sands in crystalline uplifted basements of granitic to granodioritic terrains and inputs from low to high-grade metasediments. This inferred provenance is consistent with the regional geological setting, as the outcome of a period of Alpine tectogenesis of the Spanish Central System (Álvaro et al., 1979).

The importance of recycling processes in the genesis of detritic material (sedimenticlastics sensu Arribas and Tortosa, 2003) has been stressed by several authors (Blatt and Jones, 1975; Ingersoll, 1983; Garrels, 1986) and several criteria for the petrographic differentiation of recycled sediments have been defined (Folk, 1974; Zuffa, 1987; Arribas et al., 1990; Arribas and Tortosa, 2003). The presence of meta-sedimentary rock fragments (Fig. 4b), of rounded quartz grains (Fig. 4f) together with other highly angular grains, etc., could be indicative of recycling processes occurring in the Somosaguas sediments. These would be perhaps related to tectonic reactivation of the Spanish Central System mountains during the middle Miocene.

Finally, the indices and parameters used in this study (Tables 3, 4 and 5) serve to identify differences between the six samples collected from the unit T3 (N-4.1 to N-4.6), confirming the variations observed by Fesharaki (2005), Élez (2005) and Hernández Fernández et al. (2006) between the different T3 levels. Such differences could point to a multi-episodic process, with sediments deposited by different pulses.

\subsection{Palaeoclimate analysis}

As revealed by Fesharaki et al. (2007), who examined sequences of phyllosilicate alteration and neoformation, physical and chemical alteration in the Somosaguas area is likely to have been moderate with a tendency towards reduced chemical weathering when approaching unit T3 (sensu the physicochemical alteration diagram proposed by Wilson, 1969). In work by Carrasco et al. (2008) conducted on clays associated with calcretes in Somosaguas, results indicate an average annual rainfall of 100-500 mm, reflecting a semiarid to arid environment during the middle Miocene of this area according to the criteria of Khadkikar et al. (2000). Moreover, Hernández Fernández et al. (2006) defined a seasonal environment with low torrential type precipitations, and temperatures falling from 26.6 to 15.7 degrees in the period represented by the deposition of $\mathrm{T} 1$ to the top of the T3 unit (Domingo et al., 2009).

In order to confirm this palaeoclimatic evolution several diagrams have been used to obtain general trends but not the specific characteristics of each section of the Somosaguas sediments. Here we used the diagrams proposed by Suttner et al. (1981), Suttner and Dutta (1986) and Weltje (1994), in addition to other indices (Fig. 8) for the interpretation of climate signals from petrographic data. Figure 8a illustrates the variations produced in the $\mathrm{Qp} / \mathrm{F}+\mathrm{R}$ and $\mathrm{Qp}+\mathrm{Qm} / \mathrm{F}+\mathrm{R}$ indices (Suttner and Dutta, 1986) indicating a trend from T1 to T3 towards an arid climate according to increasing feldspar and rock fragment contents. Figure $8 \mathrm{~b}$ shows a similar trend from the more humid plutonic area (T1 and $\mathrm{T} 2)$ to the more arid plutonic area (T3) (Suttner et al., 1981). The bivariate plots of $\mathrm{Q} / \mathrm{F}$ and $\mathrm{Q} / \mathrm{R}$ shown in Figure $8 \mathrm{c}$ for the Somosaguas samples yielded different weathering indices deduced from Weltje et al. (1998). Thus, samples from T1 showed the higher weathering index (WI = 1 and 2), while indices for T2 and $\mathrm{T} 3$ were lower $(\mathrm{WI}=0)$, but always plotted on the diagram side assigned to the plutonic source area. This tendency is indicative of an increase in aridity from $\mathrm{T} 1$ to $\mathrm{T} 3$.

For a given sedimentary basin with defined geotectonic characteristics, differences in alluvial sand composition indicate climate variations and these can therefore be compared (Suttner and Dutta, 1986). Assuming a granite-gneissic provenance and medium grain size, the ratios $\mathrm{Q} / \mathrm{F}$ and $\mathrm{P} / \mathrm{F}$ can be used as climate guides (Basu, 1976; Table 5). Following Basu (1976), Q/F values lower than 1 correspond to drier areas and those greater than 1 to less arid areas. Hence, the trend observed is once again one of increasing aridity when moving from T1 to T3. Similarly, our P/F values increasingly closer to 0.5 indicate an increase in aridity towards the top of the sequence.

The trend shown in the QFR diagram (Fig. 5b) is indicative of a decrease in mineralogical maturity of the Somosaguas sandy deposits and thus an increase in dry conditions (Blatt, 1967; Basu, 1976). The QmFLt and QmKP diagrams (Figs. $5 \mathrm{c}, \mathrm{d})$ indicate the preservation of feldspars towards the top of the Somosaguas succession, and a remarkable increase in plagioclase grains towards the $\mathrm{T} 3$ unit. Contrary to what we might expect for distal sediments (Breyer and Bart, 1978; Mack, 1978; Cavazza et al., 1993; Ingersoll et al., 1993; Arribas et al., 2000), T2 shows no significant reduction in rock fragments and feldspars relative to the other units. This could reflect the fact that increasing aridity will help preserve a higher percentage of feldspar and rock fragment grains. Another proof that points to an increse of the aridity is the presence of laminar calcretes interbedded with siliciclastic debris flow deposits in the upper part of unit T3, because this calcretes are indicative of semi-arid conditions (Suttner and Dutta, 1986; Alonso-Zarza, 2003). The increase towards the top of the succession of less altered plagioclase crystals could also suggest a decrease in precipitation and thus in chemical alteration of plagioclases (Fig. 3, Table 5).

Climate affects the composition of sands through its influence on pedogenic processes and chemical weathering-leaching, which destroy the bedrock (Basu, 1976; James et al., 1981; Suttner et al., 1981). The pedogenesis process converts 
a small population of rock fragments into a large variety of rock fragment populations of smaller size, including monomineral grains and pollycrystalline quartz (Suttner and Dutta, 1986). Basu (1976) pointed out that greatest physical alteration of bedrock and size selectivity of sediments occurs in soils. The presence in the Somosaguas sediments of embayed quartz grains (Fig. 4G; Crook, 1968; Cleary and Conolly, 1972; Le Pera et al., 2001) and low charge beidellites (Righi et al., 1995; Fesharaki et al., 2007) supports the idea of weak soil development during pauses in sedimentation occurring in geomorphologically higher areas with subsequent erosion and transport to the Somosaguas area.

Finally, the presence of irregular to rounded micritic carbonate clasts, which sometimes include smaller quartz and feldspar grains and sometimes show intergrowth with clays and oxides/hydroxides, would be indicative of reworking processes (Fig. 4c). The origin of these grains is related to the more or less incipient development of laminar calcretes (Sanz et al., 1995) and their subsequent reworking (GómezGras and Alonso-Zarza, 2003) which supports the idea of soils formation and their subsequent erosion during the more arid seasons. Also the rip-up clasts observed in these sediments are common in reworked sediments from alluvial fans in semiarid environments.

All the previous petrographic observations are fully consistent with the trend observed in Somosaguas area in other researches based on palaeontologic (Hernández Fernández et al., 2006), mineralogic (Fesharaki et al., 2007; Carrasco et al., 2008) and isotopic (Hernández Fernández et al., 2006; Domingo et al., 2009) data, and confirm the recording of increasing aridity and decreasing temperatures during the middle Aragonian in the Madrid Basin (Domingo et al., 2012a). These variations could be assigned to the climate event recorded globally after the Miocene Climatic Optimum (Zachos et al., 2001; Böhme, 2003; Domingo et al., 2012a).

\section{Conclusions}

The results of our light mineral petrography study support the findings of prior studies (palaeontological, mineralogical and isotopic studies) and confirm the usefulness of this type of analysis to address palaeoclimate trends. Climate was semiarid and seasonal with a trend towards increasing aridity and falling temperatures during the deposition of the Somosaguas sediments. This climate event recorded in Somosaguas was coeval with the global climate change produced after the Miocene Climatic Optimum. Using petrographic data we infer a granitic-gneissic mixed origin for the Somosaguas sediments with a small contribution of recycled meta-sedimentary and low-grade metamorphic materials from eroded coverts. Moreover, the T3 unit was confirmed as a multiepisodic deposit showing different petrographic features in its six levels, separated by reactivation surfaces, and previously proposed as different sedimentary pulses. Soil formation processes are evident in the study area and reworking processes were distinguished in the analyzed sediments, which is consistent with the multiepisodic deposition of the Somosaguas deposits. All these processes are consistent with the geotectonic setting of an "uplifted basement" infered for this area.

\section{Acknowledgements}

This work received contribution from the projects research DGICYT, CGL2008 01648, CGL2011-22709 and CGL2009/09000. We thank Guillermo Benítez for his company during the field campaings, Ana Rosa Gómez Cano for her help with graphics, and also Carmen Valdehita, Marian Barajas and Pedro Lozano for their help for samples preparation. Salvatore Critelli, Manuel Hernández Fernández and Said Fesharaki are aknowledged for their comments in the inicial drafts of this work. The authors thank Ana Burton (www.physicalevidence.es) for editorial assistance and English style checking. Finally, we acknowledge Abhijit Basu and an anonimous reviewer for their useful suggestions that helped to improve the final version of this paper. This work is in memory of Nieves López Martínez who passed away prematurely during the execution of this research.

\section{References}

Alonso-Zarza, A.M. (2003): Palaeoenvironmental significance of palustrine carbonates and calcretes in the geological record. Earth-Science Reviews 60, 261-298. doi.org/10.1016/S0012-8252(02)00106-X

Alonso-Zarza, A.M., Calvo, J.P. (2002): Tajo Basin. In: W. Gibbons and T. Moreno (eds.), The Geology of Spain. The Geological Society, London: $315-320$.

Alonso-Zarza, A.M., Calvo, J.P., Silva, P.G., Torres, T. (2004): Cuenca del Tajo. In: J.A. Vera (ed.), Geología de España. SGE-IGME, Madrid, Spain: 556-561.

Álvaro, M., Capote, R., Vegas, R. (1979): Un modelo de evolución geotectónica para la Cadena Celtibérica. Acta Geológica Hispánica 14, 172-177.

Aparicio Yagüe, A., García Cacho, L. (1984): Geología del Sistema Central español. Consejería de Política Territorial, C.S.I.C, Madrid: 32 p.

Arribas, M.E. (1985): Sedimentología y diagénesis de las facies carbonaticas del Paleógeno del Sector NW de la Cuenca del Tajo. Ph.D thesis, Universidad Complutense de Madrid, Spain: 444 p.

Arribas, J., Arribas, M.E. (1991): Petrographic evidence of different provenance in two alluvial fan systems (Palaeogene of the northern Tajo Basin, Spain). In: A.C. Morton, S.P. Todd and P.D.W. Haughton (eds.), Developments in Sedimentary Provenance Studies. Geological Society Special Publication 57: 263-271.

Arribas, J., Alonso, A., Mas, R., Tortosa, A., Rodas, M., Barrenechea, J., Alonso-Azcárate, J., Artigas, R. (2003): Sandstone petrography of continental depositional sequences of an intraplate rift basin: western Cameros Basin (North Spain). Journal of Sedimentary Research 73, 309-327. doi: 10.1306/082602730309

Arribas, J., Tortosa, A. (2003): Detrital modes in sedimenticlastic sand from low-order streams in the Iberian Range, Spain: the potential for sand generation by different sedimentary rocks. Sedimentary Geology 159, 275-303. doi:10.1016/S0037-0738(02)00332-9

Arribas, J., Critelli, S., Le Pera, E., Tortosa, A. (2000): Composition of modern stream sand derived from a mixture of sedimentary and metamorphic source rocks (Henares River, Central Spain). Sedimentary Geology 133, 27-48. doi:10.1016/S0037-0738(00)00026-9 
Arribas, J., Gómez-Gras, D., Rosell, J., Tortosa, A. (1990): Estudio comparativo entre las areniscas paleozoicas y triásicas de la isla de Menorca: Evidencias de procesos de reciclado. Revista de la Sociedad Geológica de España 3, 105-116

Basu, A. (1976): Petrology of Holocene fluvial sand derived from plutonic source rocks: implications to paleoclimatic interpretation. Journal of Sedimentary Petrology 46, 694-709. doi: 10.1306/212F70312B24-11D7-8648000102C1865D

Basu, A. (1985): Influence of climate and relief on compositions of sands released at source areas. In: G.G. Zuffa (ed.), Provenance of Arenites. Reidel, Dordrecht: 1-18.

Basu, A., Young, S.W., Suttner, L.J., James, W.C. And Mack, G.H. (1975): Re-evaluation of the use of undulatory extinction and pollycrystallinity in detrital quartz for provenance interpretation. Journal of Sedimentary Petrology 45, 873-882. doi:10.1306/212F6E6F-2B2411D7-8648000102C1865D

Benayas, J., Pérez Mateos, J., Riba, O. (1960): Asociación de minerales detríticos en los sedimentos de la cuenca del Tajo. Anales de Edafología 11, 635-671.

Blatt, H. (1967): Provenance determinations and recycling of sediments. Journal of Sedimentary Petrology 37, 1031-1044. doi:10.1306/74D71825-2B21-11D7-8648000102C1865D

Blatt, H., Jones, R.L. (1975): Proportions of exposed igneus, metamorphic, and sedimentary rocks. Geological Society American Bulletin 86, 1085-1088. doi: 10.1130/0016-7606(1975)86<1085:POEIMA $>2$ .0. $\mathrm{CO} ; 2$

Böhme, M. (2003): The Miocene Climatic Optimum: evidence from ectothermic vertebrates of Central Europe. Palaeogeography, Palaeoclimatology, Palaeoecology 195, 389-401. doi:10.1016/S00310182(03)00367-5

Breyer, J.A., Bart, H.A. (1978): The composition of fluvial sands in a temperate semiarid region. Journal of Sedimentary Petrology 48, 1311-1320. doi:10.1306/212F7671-2B24-11D7-8648000102C1865D

Calvo, J.P., Alonso-Zarza, A.M., García Del Cura, M.A. (1989a): Models of marginal lacustrine sedimentation as a response to depositional regimes and source rocks in the Madrid Basin. Palaeogeography, Palaeoclimatology, Palaeoecology 70, 199-214. doi.org/10.1016/00310182(89)90090-4

Calvo, J.P., Daams, R., Morales, J., López Martínez, N., Agustí, J., Anadon, P., Armenteros, I., Cabrera, L., Civis, J., Corrochano, A., DíazMolina, M., Elizaga, E., Hoyos, M., Martín-Suárez, E., Martínez, J., Moissenet, E., Muñoz, A., Pérez-García, A., Pérez-González, A., Portero, J.M., Robles, F., Santisteban, C., Torres, T., Van Der Meulen, A.J., Vera, J.A., Mein, P. (1993): Up-to-date Spanish continental Neogene synthesis and paleoclimatic interpretation. Revista de la Sociedad Geológica de España 63, 29-40.

Calvo, J.P., Ordóñez, S., García Del Cura, M.A., Hoyos, M., AlonsoZarza, A.M., Sanz, E., Rodríguez Aranda, J.P. (1989b): Sedimentología de los complejos lacustres miocenos de la Cuenca de Madrid. Acta Geológica Hispánica 24, 281-298.

Carrasco, A., Sacristán, S., Benítez-López, G., Romero-Nieto, D., Fesharaki, O., López Martínez, N. (2008): Aplicaciones paleoclimáticas y paleoambientales de los estudios mineralógicos al yacimiento de vertebrados miocenos de Somosaguas. Palaeontologica Nova 8, 135149.

Cavazza, W., Zuffa, G.G., Camporesi, C., Ferretti, C. (1993): Sedimentary recycling in a temperate climate drainage basin (Senio River, north-central Italy): composition of source rock, soil profiles, and fluvial deposits. In: M.J. Johnsson and A. Basu (eds.), Processes Controlling the Composition of Clastic Sediments. Geological Society of America, Special Paper 284: 247-261.

Chayes, F. (1952): Notes on the staining of potash feldspar with sodium cobaltinitrite in thin section. American Mineralogist 37, 337-340.

Chayes, F. (1956): Petrographic modal analysis. John Wiley and Sons,
New York: 113 p.

Cleary, W.J., Conolly, J.R. (1972): Embayed quartz grains in soils and their significance. Journal of Sedimentary Petrology 42, 899-904. doi:10.1306/74D7266C-2B21-11D7-8648000102C1865D

Crook, K.A.W. (1968): Weathering and roundness of quartz sand grains. Sedimentology 11, 171-182. DOI: 10.1111/j.1365-3091.1968. tb00851.x

De Vicente, G., Calvo, J.P., Muñoz Martín, A. (1996): Neogene tectono-sedimentary review of the Madrid Basin. In: P.F. Friend and C.J. Dabrio (eds.) Tertiary basins of Spain. University Press, Cambridge: 268-271.

De Vicente, G., Vegas, R., Muñoz Martín, A., Silva, P.G., Andriessen, P., Cloetingh, S., González Casado, J.M., Van Wees, J.D., Álvarez, J., Carbó, A., Olaiz, A. (2007): Cenozoic thick-skinned deformation and topography evolution of the Spanish Central System. Global and Planetary Change 58, 335-381. doi:10.1016/j.gloplacha.2006.11.042

Di Giulio, A., Tribuzio, R., Ceriani, A., Riccardi, M.P. (1999): Integrated analyses constraining the provenance of sandstones, a case study: the Section Peak Formation (Beacon Supergroup, Antarctica). Sedimentary Geology 124, 169-183.

Dickinson, W.R. (1970): Interpreting detrital modes of graywacke and arkose. Journal of Sedimentary Petrology 40, 695-707. doi:10.1306/74D72018-2B21-11D7-8648000102C1865D

Dickinson, W.R., Beard, L.S., Brakenridge, G.R., Erjavec, J.L., Ferguson, R.C., Inman, K.F., Knepp, R.A., Lindberg, F.A., Ryberg, P.T. (1983): Provenance of North American Phanerozoic sandstones in relation to tectonic setting. Geological Society of America Bulletin 94, 222-235. doi:10.1130/0016-7606(1983)94<222:PONAPS $>2.0 . C O ; 2$

Dickinson, W.R. (1985): Interpreting provenance relations from detrital modes of sandstones. In: G.G. Zuffa (ed.), Provenance of arenites. Dordrecht, D. Reidel: 333-361.

Dickinson, W.R. (1988): Provenance and sediments dispersal in relation to paleotectonics and paleogeography of sedimentary basins. In: K.L. Kleinspehn and C. Paola (eds.), New Perspectives in Basin Analysis, Springer Verlag, New York: 3-25.

Dickinson, W.R., Suczek, C.A. (1979): Plate tectonics and sandstone compositions. American Association of Petroleum Geologists Bulletin 63, 2164-2182.

Dickinson, W.R., Valloni, R. (1980): Plate settings and provenance of sands in modern ocean basins. Geology 8, 82-86. doi:10.1130/00917613(1980) $8<82$ :PSAPOS $>2.0$. CO;2

Díez-Canseco, D., López Martínez, N., Díaz-Molina, M., Benito, M.I. (2012): Stream mouth deposits in the paleontological site of Somosaguas, middle Miocene, Madrid basin. Spanish Journal of Palaeontology $27,93-101$.

Domingo, L., Cuevas-González, J., Grimes, S.T., Hernández Fernández, M., López Martínez, N. (2009): Multiproxy reconstruction of the palaeoclimate and palaeoenvironment of the middle Miocene Somosaguas sites (Madrid, Spain) using herbivore dental enamel. Palaeogeography, Palaeoclimatology, Palaeoecology 272, 53-68. doi:10.1016/j.palaeo.2008.11.006

Domingo, L., Koch, P.L., Grimes, S.T., Morales, J., López Martínez, N. (2012a): Isotopic paleoecology of mammals and the Middle Miocene Cooling event in the Madrid Basin (Spain). Palaeogeography, Palaeoclimatology, Palaeoecology 339, 98-113. doi:10.1016/j.palaeo.2012.04.026

Domingo, L., López Martínez, N., Grimes, S.T. (2012b): Trace element analyses indicative of paleodiets in Middle Miocene mammals from the Somosaguas site (Madrid, Spain). Geologica Acta 10, 239-247. DOI: $10.1344 / 105.000001746$

Élez, J. (2005): Aplicación GIS 3D a los yacimientos paleontológicos de Somosaguas. Unpublished Advanced Studies Diploma, Universidad Complutense de Madrid: $39 \mathrm{p}$.

Fesharaki, O. (2005): Mineralogía y Sedimentología del yacimiento 
Paleontológico de Somosaguas (Mioceno, Cuenca de Madrid). Unpublished Advanced Studies Diploma, Universidad Complutense de Madrid: $147 \mathrm{p}$.

Fesharaki, O., García Romero, E., Cuevas-González, J., López Martínez, N. (2007): Clay mineral genesis and chemical evolution in the Miocene sediments of Somosaguas, Madrid Basin, Spain. Clay Minerals 42, 187-201. doi:10.1180/claymin.2007.042.2.05

Fesharaki, O., Torices, A., García Yelo, B.A., Tejedor-Navarro, N., De la Ossa, L., Hernández Fernández, M. (2012): The Somosaguas Palaeontology Project: An envision of Nieves López Martínez for linking science and society. Spanish Journal of Paleontology 27, 83-92.

Folk, R.L. (1974): Petrology of sedimentary rocks. Hemphill Publishing Co., Austin, Texas: $182 \mathrm{p}$.

Franzinelli, E., Potter, P.E. (1983): Petrology, chemistry, and texture of modern river sands, Amazon River system. Journal of Geology 91, 23-39.

García Yelo, B.A, Gómez Cano, A.R., Cantalapiedra, J.L., Alcalde, G.M., Sanisidro, O., Oliver, A., Hernández-Ballarín, V., López-Guerrero, P., Fraile, S., Hernández Fernández, M. (2014): Palaeoenvironmental analysis of the Aragonian (middle Miocene) mammalian faunas from the Madrid Basin based on body-size structure. Journal of Iberian Geology 40, 129-140.

Garrels, R.M. (1986): Sediment cycling and diagenesis. U.S. Geological Survey Bulletin 1578, 1-11.

Gazzi, P. (1966): Le Arenarie del Flysch Sopracretaceo dell'Appennino Modenese: Correlazioni con il Flysch di Monghidoro. Mineralogica et Petrografica Acta 12, 69-97.

Glagolev, A.A. (1933): On geometrical methods of quantitative mineralogical analysis of Rocks. Trans. Inst. Economic Mineralogy 59, 1-47.

Gómez-Gras, D., Alonso-Zarza, A.M. (2003): Reworked calcretes: their significance in the reconstruction of alluvial sequences (Permian and Triassic, Minorca, Balearic Islands, Spain). Sedimentary Geology 158, 299-319. doi:10.1016/S0037-0738(02)00315-9

Hernández Fernández, M., Cárdaba, J.A., Cuevas-González, J., Fesharaki, O., Salesa, M.J., Corrales, B., Domingo, L., Elez, J., López Guerrero, P., Sala-Burgos, N., Morales, J., López Martínez, N. (2006): Los yacimientos de vertebrados del Mioceno medio de Somosaguas (Pozuelo de Alarcón, Madrid): implicaciones paleoambientales y paleoclimáticas. Estudios Geológicos 62, 263-294.

Hernández-Ballarín, V., Oliver, A., Peláez-Campomanes, P. (2011): Revisión de las asociaciones de mamíferos del tránsito Aragoniense medio y superior de la Cuenca de Madrid. In: A. Pérez-García, F. Gascó, J.M. Gasulla and F. Escaso (eds.), Viajando a mundos pretéritos, Ayuntamiento de Morella, Castellón: 173-182.

Ingersoll, R.V. (1978): Petrofacies and petrologic evolution of the Late Cretaceous fore-arc basin, northern and central California. Journal of Geology 86, 335-352.

Ingersoll, R.V. (1983): Petrofacies and provenance of late Mesozoic forearc basin, northern and central California. American Association of Petroleum Geologists Bulletin 67, 1125-1142.

Ingersoll, R.V., Suczek, C.A. (1979): Petrology and provenance of Neogene sand from Nicobar and Bengal fans, DSDP sites 211 and 218. Journal of Sedimentary Petrology 49, 1217-1228. doi:10.1306/212F78F1-2B24-11D7-8648000102C1865D

Ingersoll, R.V., Kretchmer, A.G., Valles, P.K. (1993): The effect of sampling scale on actalistic sandstone petrofacies. Sedimentology 40, 937-953. DOI: 10.1111/j.1365-3091.1993.tb01370.x

Ingersoll, R.V., Bullard, T.F., Ford, R.L., Grimm, J.P., Pickle, J.P., Sares, S.W. (1984): The effect of grain size on detrital modes: a test of the Gazzi-Dickinson Point-Counting method. Journal of Sedimentary Petrology 54, 103-116. doi:10.1306/212F83B9-2B24-11D78648000102C1865D

James, W.C., Mack, G.H., Suttner, L.J. (1981): Relative alteration of microcline and sodic plagioclase in semi-arid and humid climates. Jour- nal of Sedimentary Petrology 51, 151-164. doi:10.1306/212F7C342B24-11D7-8648000102C1865D

Johnsson, M.J. (1993): The system controlling the composition of clastic sediments. In: M.J. Johnsson and A. Basu (eds.), Processes Controlling the Composition of Clastic Sediments. Geological Society of America, Special Paper 284: 1-19.

Junco, F., Calvo, J.P. (1983): Cuenca de Madrid. In: Libro Homenaje a J.M. Ríos (II). Geología de España. IGME, Madrid: 534-542.

Khadkikar, A.S., Chamyal. L.S., Ramesh, R. (2000): The character and genesis of calcrete in late Quaternary alluvials deposits, Gujarat, western India, and its bearing on interpretation of ancient climates. Palaeogeography, Palaeoclimatology, Palaeoecology 162, 239-261.

Le Pera, E., Arribas, J. (2004): Sand composition in an Iberian passivemargin fluvial course: the Tajo River. Sedimentary Geology 171, 261281. doi:10.1016/j.sedgeo.2004.05.019

Le Pera, E., Arribas, J., Critelli, S., Tortosa, A. (2001): The effects of source rocks and chemical weathering on the petrogenesis of siliciclastic sand from Neto River (Calabria, Italy): implications for provenance studies. Sedimentology 48, 357-378. DOI: 10.1046/j.13653091.2001.00368.x

Le Pera, E.; Critelli, S. (1997): Sourceland controls on the composition of beach and fluvial sand of the northern Tyrrhenian coast of Calabria, Italy: implications for actualistic petrofacies. Sedimentary Geology 110, 81-97.

López Martínez, N., Élez, J., Hernando, J.M., Luís, A., Mazo, A., Mínguez Gandú, D., Morales, J., Polonio, I., Salesa, M.J., Sánchez, I. (2000): Los fósiles de vertebrados de Somosaguas (Pozuelo, Madrid). Coloquios de Paleontología 51, 69-86.

López Olmedo, F., Díaz De Neira, A., Martín Serrano, A., Calvo, J.P., Morales, J., Peláez-Campomanes, P. (2004): Unidades estratigráficas en el registro sedimentario neógeno del sector occidental de la Cuenca de Madrid. Revista de la Sociedad Geológica de España 171, 87-101.

Luís, A., Hernando, J.M. (2000): Los microvertebrados fósiles del Mioceno Medio de Somosaguas Sur Pozuelo de Alarcón, Madrid, España. Coloquios de Paleontología 51, 87-136.

Mack, G.H., (1978): The survavility of labile light-mineral grains in fluvial, aeolian and litoral marine environments: the Permian Cutler and Cedar Mesa Formations, Moab, Utah. Sedimentology 25, 587-604. DOI: 10.1111/j.1365-3091.1978.tb00321.x

Mack, G.H. (1981): Composition of modern stream sand in a humid climate derived from a low-grade metamorphic and sedimentary foreland fold-thrust belt of north Georgia. Journal of Sedimentary Petrology $51,1247-1258$.

Mack, G.H. (1984): Exceptions to the relationship between plate tectonics and sandstone composition. Journal of Sedimentary Petrology 54, 212-220. doi:10.1306/212F83E6-2B24-11D7-8648000102C1865D

Mason, R. (1990): Petrology of the Metamorphic Rocks. Unwin Hyman, London: $230 \mathrm{p}$.

Megías, A.G., Ordóñez, S., Calvo, J.P. (1983): Nuevas aportaciones al conocimiento geológico de la Cuenca de Madrid. Revista de Materiales y Procesos Geológicos 1, 163-191.

Mínguez Gandú, D. (2000): Marco estratigráfico y sedimentológico de los yacimientos paleontológicos miocenos de Somosaguas Madrid, España. Coloquios de Paleontología 51, 183-196.

Montes, M., Beamud, B., Garcés, M., Calvo, J.P. (2006): Magnetoestratigrafía de las Unidades Inferior e Intermedia del Mioceno de la Cuenca de Madrid. Revista de la Sociedad Geológica de España 19 (3-4), 281-298.

Ordóñez, S., Calvo, J.P., García Del Cura, M.A., Alonso-Zarza, A.M., Hoyos, M. (1991): Sedimentology of sodium sulphate deposits and special clays from the Tertiary Madrid Basin (Spain). In: P. Anadón, L. Cabrera and K. Kelts (eds.), Lacustrine Facies Analysis, Special Publications International Association of Sedimentologists 13: 39-55. Palomares, M., Arribas, J. (1993): Modern stream sands from compound 
crystallyne sources: Composition and sand generation index. In: M.J. Johnsson and A. Basu (eds.), Processes controlling the composition of clastic sediments, Geological Society of America, Special Paper 284: 313-322.

Palomares, M., Tortosa, A., Arribas, J. (1990): Caracterización clastométrica de los depósitos detríticos de cabecera de arroyos en el Sistema Central: influencia de la litología del área fuente. Boletín de la Real Sociedad Española de Historia Natural 85, 5-21.

Peláez-Campomanes, P., Morales, J., Álvarez Sierra, M.A., Azanza, B., Fraile, S., García Paredes, I., Hernández Fernández, M., Herráez, E., Nieto, M., Pérez, B., Quiralte, V., Salesa, M.J., Sánchez, I.M., Soria, D. (2003): Updated biochronology of the Miocene mammals fauna from the Madrid basin (Spain). Deinsea 10, 431-441.

Perales, R., Serrano, H., García Yelo, B.A., Hernández Fernández, M. (2009): Inferencias paleoambientales del Mioceno medio de Somosaguas (Pozuelo de Alarcón, Madrid) basadas en la estructura de tamaños corporales de su fauna de mamíferos. Paleolusitana 1, 317-325.

Pettijohn, F.J. (1957): Sedimentary Rocks. 2nd Edition, Harper, New York: $718 \mathrm{p}$.

Pettijohn, F.J., Potter, P.E., Siever, R. (1972): Sand and Sandstone. Springer-Verlag, Berlin: $770 \mathrm{p}$.

Riba, O. (1959): Ensayo sobre la distribución de litofacies del Terciario continental de la Cuenca del Tajo al $W$ de la Sierra de Altomira. Cursillos y Conferencias, Instituto Lucas Mallada 4.

Righi, D., Terribile, F., Petit, S. (1995): Low-charge to high-charge beidellite conversion in a vertisol from South Italy. Clays and Clay Minerals 43, 495-502. DOI: 10.1346/CCMN.2010.0580209

Sanz, M.E., Alonso-Zarza, A.M., Calvo, J.P. (1995): Carbonate pond deposits related to semi-arid alluvial Systems:examples from the Tertiary of of Madrid Basin, Spain. Sedimentology 42, 437-452. DOI: 10.1111/j.1365-3091.1995.tb00383.x

Sopeña, A. (Editor) (2004): Cordillera Ibérica y Costero Catalana. In: J.A. Vera (ed.), Geología de España. SGE-IGME, Madrid, Spain: 587-634.

Suttner, L.J., Dutta, P.K. (1986): Alluvial sandstone composition and paleoclimate I: Framework mineralogy. Journal of Sedimentary Petrology 56, 329-345. doi:10.1306/212F8909-2B24-11D7$8648000102 \mathrm{C} 1865 \mathrm{D}$

Suttner, L.J., Basu, A., Mack, G.H. (1981): Climate and the origin of Quartz arenitas. Journal of Sedimentary Petrology 51, 1235-1246. doi:10.1306/212F7E73-2B24-11D7-8648000102C1865D

Torres, T., Maldonado, A., Querol, R., Zamora, I. (1995): Evolución en el subsuelo de los sistemas de abanicos aluviales del Mioceno de la cuenca de Madrid (España). Geogaceta 18, 56-58.

Tortosa, A., Palomares, M., Arribas, J. (1988): Tipologías de cuarzo como indicadores de la procedencia en areniscas: excepciones al método de Basu et al. (1975). Estudios Geológicos 44, 385-390.

Tortosa, A., Palomares, M., Arribas, J. (1989): Caracterización com- posicional de los depósitos arenosos actuales generados en el Sistema Central. Estudios Geológicos 45, 205-213.

Tortosa, A., Palomares, M., Arribas, J. (1991): Quartz grain types in Holocene deposits from the Spanish Central System: some problems in provenance analysis. In: A.C. Morton, S.P. Todd and P.D.W. Haughton (eds.), Developments in Sedimentary Provenance Studies, Geological Society Special Publication 57: 47-54.

Van Der Meulen, A., Daams, R. (1992): Evolution of Early-Middle Miocene rodent faunas in relation to long-term palaeoenvironmental changes. Palaeogeography, Palaeoclimatology, Palaeoecology 93, 227-253.

Vegas, R., Banda, S. (1982): Tectonic framework and Alpine evolution of the Iberian Peninsula. Earth Evolution Sciences 4, 320-343.

Villaseca, C., Andonaegui, P., Barbero, L. (1993): Mapa geológico del plutonismo Hercínico de la región central española (Sierra de Guadarrama y Montes de Toledo). Mapa Geológico de España E. 1:150.000. CSIC, Madrid.

Weltje, G.J. (1994): Provenance and dispersal of sand-sized sediments: Reconstruction of dispersal patterns and sources of sand-sized sediments by means of inverse modelling techniques. $\mathrm{PhD}$ thesis, Utrecht University: $125 \mathrm{p}$

Weltje, G.J., Meijer, X.D., De Boer, P.L. (1998): Stratigraphic inversion of siliciclastic basin fills: a note on the distinction between supply signals resulting from tectonic and climatic forcing. Basin Research 10, 129-153. DOI: 10.1046/j.1365-2117.1998.00057.x

Wilson, L. (1969) : Les relations entre les processus géomorphologiques et le climat moderne comme méthod de paleoclimatologie. Revue de Géographie Physique et de Géologie Dynamique 11, 301-314.

Young, S.W. (1976): Petrographic textures of detrital polycrystalline quartz as an aid to interpreting crystalline source rocks. Journal of Sedimentary Petrology 46, 595-603. doi:10.1306/212F6FFA-2B2411D7-8648000102C1865D

Young, S.W., Basu, A., Mack, G., Darnell, N, Suttner, L.J. (1975): Use of size-composition trends in Holocene soil and fluvial sand for paleoclimatic interpretations. Proceedings of the IXth International Congress Sedimentology, Nice, France.

Zachos, J., Pagani, M., Sloan, L., Thomas, E., Billups, K. (2001): Trends, rhythms, and aberrations in global climate 65 Ma to present. Science 292, 686-693. DOI: 10.1126/science. 1059412

Zuffa, G.G. (1980): Hybrid arenites: their composition and classification. Journal of Sedimentary Petrology 50, 21-29. doi:10.1306/212F79502B24-11D7-8648000102C1865D

Zuffa, G.G. (1985): Optical analyes of arenites: Influence of methodology on compositional results. In: G.G. Zuffa (ed.), Provenance of arenites. Dordrecht, Reidel: 165-189.

Zuffa, G.G. (1987): Unravelling hinterland and offshore palaeogeography from deep-water arenites. In: J.K. Leggett and G.G. Zuffa (eds.), Concepts and case studies, Graham and Trotman, London: 39-61. 